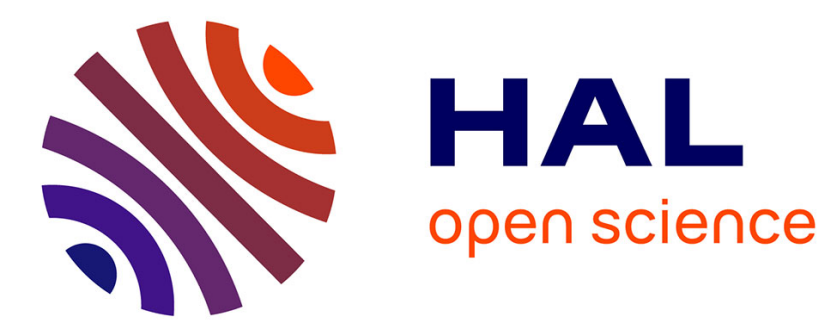

\title{
Diversity and biological significance of sex hormone-binding globulin in fish, an evolutionary perspective
}

Julien Bobe, Yann Guiguen, Alexis Fostier

\section{- To cite this version:}

Julien Bobe, Yann Guiguen, Alexis Fostier. Diversity and biological significance of sex hormonebinding globulin in fish, an evolutionary perspective. Molecular and Cellular Endocrinology, 2009, 316 (1), pp.66. 10.1016/j.mce.2009.09.017 . hal-00550179

\section{HAL Id: hal-00550179 \\ https://hal.science/hal-00550179}

Submitted on 24 Dec 2010

HAL is a multi-disciplinary open access archive for the deposit and dissemination of scientific research documents, whether they are published or not. The documents may come from teaching and research institutions in France or abroad, or from public or private research centers.
L'archive ouverte pluridisciplinaire HAL, est destinée au dépôt et à la diffusion de documents scientifiques de niveau recherche, publiés ou non, émanant des établissements d'enseignement et de recherche français ou étrangers, des laboratoires publics ou privés. 


\section{Accepted Manuscript}

Title: Diversity and biological significance of sex

hormone-binding globulin in fish, an evolutionary perspective

Authors: Julien Bobe, Yann Guiguen, Alexis Fostier

PII: $\quad$ S0303-7207(09)00500-0

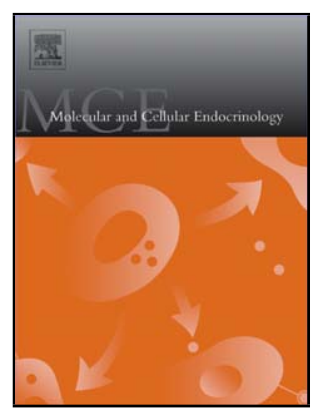

DOI: doi:10.1016/j.mce.2009.09.017

Reference: MCE 7329

To appear in: Molecular and Cellular Endocrinology

Received date:

26-5-2009

Revised date:

Accepted date: 16-9-2009

Please cite this article as: Bobe, J., Guiguen, Y., Fostier, A., Diversity and biological significance of sex hormone-binding globulin in fish, an evolutionary perspective, Molecular and Cellular Endocrinology (2008), doi:10.1016/j.mce.2009.09.017

This is a PDF file of an unedited manuscript that has been accepted for publication. As a service to our customers we are providing this early version of the manuscript. The manuscript will undergo copyediting, typesetting, and review of the resulting proof before it is published in its final form. Please note that during the production process errors may be discovered which could affect the content, and all legal disclaimers that apply to the journal pertain. 


\section{Diversity and biological significance of sex hormone-}

\section{binding globulin in fish, an evolutionary perspective}

Julien Bobe, Yann Guiguen, Alexis Fostier

INRA, UR1037 SCRIBE, IFR140, Ouest-Genopole, F-35000 Rennes, France

Corresponding author:

J Bobe

INRA, UR1037 SCRIBE, Fish Reproduction Group, Campus de Beaulieu, F-35000 Rennes,

France

Email : $\underline{\text { Julien.Bobe@ rennes.inra.fr }}$

Tel : (+33) 223485724

Fax : (+33) 223485020 


\section{Keywords}

Shbga, Shbgb, Estradiol, Steroids, teleosts, Trout

\section{Abtract}

In fish, two different genes, shbga and shbgb, exist that encode for very different proteins.

Shbga is the ortholog of mammalian Shbg and was found in all investigated teleosts. In contrast, Shbgb is highly divergent and appears to be a salmonid-specific protein. Here, we review existing data on fish Shbga and Shbgb that have been obtained in chondrichthyes and osteichtyes. Even though other significant expression sites exist, existing data indicate that Shbga is mainly expressed in liver and subsequently secreted into the blood as a homodimer. In contrast, Shbgb is mainly expressed in the ovary, probably secreted as a monomer, and could contribute to the regulation of local steroid action. Binding studies indicate a specialization of circulating Shbg during evolution towards the preferential binding of estradiol and testosterone in teleosts. In contrast, specific fish steroids such as 11-oxoandrogens and oocyte maturation-inducing steroids that are crucial for reproduction are poorly bound by either form of Shbg. 


\section{Introduction}

Sex hormone-binding globulins (Shbg) are mainly known as carrier blood proteins involved in the transport of sex steroids in plasma and in the regulation of their bioavailability to target organs. The Shbg protein has initially been identified in the beta-globulin fraction of the human serum (Rosner et al., 1969). This field has subsequently benefited from many molecular studies of the genes and transcripts encoding Shbg in many mammalian species (Joseph et al., 1991;Kahn et al., 2002;Rosner, 2006;Nakhla et al., 2009) (see also reviews in the present issue). In fish, Shbg has been found in the plasma of an elasmobranch, the skate (Raja radiata) (Freeman and Idler, 1969), and of a teleost, the rainbow trout (Oncorhynchus mykiss) (Fostier and Breton, 1975) a few decades ago, and subsequently identified and studied in a wide variety of fish species as reviewed here. However, in contrast to mammals, the molecular analysis of teleost shbg genes was not carried out until recently (Miguel-Queralt et al., 2004;Miguel-Queralt et al., 2005;Bobe et al., 2008b) and available data remain scarce. Here, after providing a phylogenetic characterization of Shbg proteins in fish, we first aim at reviewing existing molecular and biochemical data that have been obtained not only in osteichtyes, but also in chondrichthyes. The recent molecular data on shbg genes will be reviewed and discussed in the light of existing biochemical data that have previously been gathered in a wide variety of species. In addition, we will take advantage of the basal evolutionary position of teleosts within the vertebrate lineage to discuss the evolution of binding characteristics of vertebrate Shbg proteins. Finally, although several alternatively spliced transcripts have been identified in mammals (Nakhla et al., 2009), it should be stressed that, in contrast to mammals, two highly divergent Shbg proteins exist in fish. Shbg alpha form (Shbga) is clearly the ortholog of the mammalian Shbg and has been found in all investigated teleost species. In contrast, the Shbg beta form (Shbgb) initially identified in 
rainbow trout (Bobe et al., 2008b) has subsequently been found in other salmonid species (Miguel-Queralt et al., 2009) but could not be identified in any other non-salmonid teleost species investigated to date. This offers a great opportunity to discuss the evolution of Shbgb binding characteristics and putative biological functions with regards to sequence divergence and conserved sequence features.

For clarity reasons, Shbga and Shbgb symbols will be used in the text when proteins with known sequences were specifically studied while Shbg symbol will be used for Shbg proteins in general or when binding or biochemical studies were carried out directly from plasma or tissues.

\section{Shbg genes, structure and evolutionary history}

\section{Evolution of fish Shbg genes}

To date, Shbg proteins have only been characterized molecularly in bony fish (osteichtyes class), more specifically in the teleost superorder that includes all modern ray-finned fish species (actinopterygians fishes). The phylogenetic reconstruction of the evolutionary history of Shbg proteins in these teleost fish (Figure. 1) indicates that most species have only one Shbg, designated as the Shbg alpha form (Shbga), that is closely related to mammalian Shbg proteins. However, in some fish species, such as the common carp (Cyprinus carpio), two duplicated genes are found (shbgal and shbga2) that are probably the result of the recent whole genome duplication reported in this species (Larhammar and Risinger, 1994). In contrast to these recent gene duplications that resulted in highly similar Shbg proteins, a highly-divergent Shbg beta form, designated as Shbgb, has been found in the salmonid lineage (Bobe et al., 2008b;Miguel-Queralt et al., 2009). The phylogenetic position of Shbgb proteins is intriguing as they all branched together with high bootstrap values at the root of the tetrapod Shbg branch (Figure. 1). This topology suggests an ancient duplication followed by a 
subsequent lost in all non-salmonid vertebrate species (Miguel-Queralt et al., 2009).

However, it is also possible that shbga and shbgb genes are the result of a duplication of a common shbg ancestor gene that occurred after salmonid radiation. The additional whole genome duplication (3R) that occurred in salmonids would be consistent with this hypothesis (Allendorf and Thorgaard, 1984). The topology of the phylogenetic tree could thus be explained by a long-branch attraction artifact that is classically observed for highly divergent sequences (Delsuc et al., 2005). It should also be stressed that accelerated molecular evolution appears to be quite frequent following fish genome duplications (Steinke et al., 2006). The high divergence between Shbga and Shbgb would thus suggest a functional shift through either sub- or neo-functionalization that would be consistent with the very different expression patterns observed (Bobe et al., 2008b;Miguel-Queralt et al., 2009).

\section{Structure of Shbg-alpha (Shbga) in teleosts}

In all species studied to date the classical Shbg (Shbga) exists as a homodimeric glycoprotein characterized by a common structure composed by two laminin G (LG) like domains that contains two sets of conserved cysteines that form intramolecular disulphide bridges. As secreted proteins, a signal peptide sequence is cleaved from the precursor protein to give rise to the mature protein. Apart from its role as a steroid carrier protein, there is some evidence that this protein can mediate steroid signaling by binding to membrane associated proteins (Hryb et al., 2002). Accordingly, a putative N-terminal membrane receptor-binding domain that could bind to specific receptors on cell membranes has been characterized in humans (Khan et al., 1990). Plasma Shbg is normally glycosylated and this is thought to influence the biological half-life of the protein (Cousin et al., 1999). Classical Shbg (Shbga) sequences in fish have been characterized recently but only in a very few number of fish species including zebrafish (Danio rerio) (Miguel-Queralt et al., 2004), Atlantic sea bass (Dicentrarchus labrax) (Miguel-Queralt et al., 2005), rainbow trout (Bobe et al., 2008b) and coho salmon 
(Miguel-Queralt et al., 2009). Other information on fish Shbg sequences can also be deduced from published cDNA, expressed sequence tags (ESTs) databases, and from the analysis of genomic sequences available in some fish species. The analysis of these sequences and their deduced proteins indicates that the fish classical Shbga proteins are typically 380-400 amino acid long. These proteins are poorly conserved at the amino-acid level as they only share 40 to $80 \%$ identity with each other, depending on their evolutionary proximity, and around $25 \%$ identity with the human sequence (Table 1). Despite this relatively poor sequence identity, all fish Shbga have classical Shbg features including, the two well conserved LG-domains (N and C-terminal) with the conserved cysteine residues that participate in the disulphide bridges, a signal peptide sequence that is cleaved from the precursor protein to produce the mature protein, and a putative N-terminal membrane receptor-binding domain (Figure 2). Fish Shbga also contain three $\mathrm{N}$-glycolysation sites that are relatively well conserved among fish sequences (Figure 2) with the exception of the Japanese medaka (Oryzias latipes) that does not share the third site of N-glycosylation (Miguel-Queralt et al., 2005). However, these Nglycosylation sites are unique to fish Shbga and are not conserved in mammalian SHBG sequences (Miguel-Queralt et al., 2005).

A few biochemical determinations of fish Shbg molecular weight have been performed on native or recombinant proteins using gel filtration and/or polyacrylamide gel electrophoresis: $80 \mathrm{Kda}$ in skate (Freeman and Idler, 1969), 150-180 Kda in spiny dogfish (Squalus Acanthias) (Ho et al., 1980), 64 Kda in Japanese eel (Anguilla japonica) (Chang et al., 1994), 194 Kda in common carp (Chang and Lee, 1992), 105 \pm 8.7 Kda in zebrafish (Miguel-Queralt et al., 2004), 118.3 $\pm 11.5 \mathrm{Kda}$ in Atlantic sea bass (Miguel-Queralt et al., 2005), and $153 \mathrm{Kda}$ for the coho salmon Shbg alpha form (Miguel-Queralt et al., 2009). With the exception of the Japanese eel these observations are in agreement with the presence of a circulating homodimer made from glycosylated subunits (Miguel-Queralt et al., 2005). Besides species differences, variability in 
molecular weights may also be due to the occurrence of Shbg aggregation / polymerization which is less pronounced when dithiothreitol or 2-mercaptoethanol was used as reducing agents in buffer preventing disulfide bonds (Freeman and Idler, 1969;Ho et al., 1980). These differences could also be due to different numbers of oligosaccharides chains since, as indicated above, three $\mathrm{N}$-glycosylation sites may be found in several species (Miguel-Queralt et al., 2004). In mammals, observed isoforms have been considered to be the result of partial use of the two N-glycosylation sites on each Shbg subunit (Danzo et al., 1989;Bocchinfuso et al., 1992;Cousin et al., 1999).

The structure of the shbga gene has been initially described in the zebrafish (Miguel-Queralt et al., 2004) in which the transcription unit encoding the Shbga protein has been found to span close to $13 \mathrm{~kb}$ in length and to contain 8 exons. This gene organization with 8 exons is well conserved in teleost fish; at least within shbga genes deduced from species with an available genome sequence (Figure 3). Despite important differences in gene length (from $2.2 \mathrm{~kb}$ for the Japanese pufferfish (Takifugu rubipres) to more than $13 \mathrm{~kb}$ in the zebrafish) all intronexon boundaries are conserved (data not shown). This highly conserved structure of the shbga gene among teleost species was not totally unexpected as the zebrafish gene organization was already found to be well conserved with the cognate human sequence, including a perfect conservation of the intron-exon boundaries (Miguel-Queralt et al., 2004). In contrast, none of the regulatory regions, that are conserved in human and rat genes, have been identified in the $1 \mathrm{~kb}$ proximal promoter of zebrafish and Japanese pufferfish shbga genes (Miguel-Queralt $e t$ al., 2004).

\section{Structure of the salmonid-specific Shbg beta form (Shbgb)}

The salmonid-specific Shbgb proteins are highly divergent Shbg proteins (Bobe et al., 2008b) as they share less identity (around 20\%) with the classical fish Shbg (Shbga) than the human SHBG with fish Shbga (around 25\%). However, despite these important sequence 
divergences (see Table 1 and Figure 2) with Shbga proteins, they still display a good structural conservation of the tandem repeats of laminin G-like domains that are crucial for steroid-binding and dimer formation, or of the putative N-terminal amino-acid stretch that could bind to a Shbg membrane receptor. This suggests some well conserved functionality even though major structural differences have been found between Shbga and Shbgb proteins. For instance, and in contrast to Shbga, the Chinook salmon Shbgb has an estimated molecular weight of $68 \mathrm{kda}$ and is only found as a monomer in plasma or when expressed as a recombinant protein (Miguel-Queralt et al., 2009). The fact that Shbgb would not homodimerize spontaneously has been correlated with the lack of the highly conserved Val89 and Leu122 (Miguel-Queralt et al., 2009) that have been found to be crucial for dimerization in human (Avvakumov et al., 2001). Other hypotheses explaining this absence of dimerization include major differences in $\mathrm{N}$-glycosylation sites, as none of these sites are conserved with the Shbga form (Figure 2), or the lack of essential cation biding sites required for this dimerization (Miguel-Queralt et al., 2009). To date, no gene structure has been reported for these highly divergent salmonid-specific shbgb genes. The gene structure information would, however, provide important information as the comparison of the vicinity of shbga and shbgb genes in salmonids would probably help to conclude whether or not these genes arise from a duplication that took place following the salmonid-specific genome duplication or following a more ancient duplication. Comparison of regulatory sequences between the proximal promoter sequences of shbga and shgbb genes may also be of great interest with regards of the important tissues specific expression of these two shbg genes. 


\section{Tissue distribution and expression sites}

\section{Shbga}

The tissue distribution of shbga transcript has been studied in a limited number of teleost species. In zebrafish, shbga mRNA was detected by in situ hybridization and RT-PCR in digestive tract and hepatopancreas (Miguel-Queralt et al., 2004). In addition, a low expression was detected in testis using RT-PCR (Miguel-Queralt et al., 2004). Using immunocytochemistry, zebrafish Shbga protein was immunodetected in hepatopancreas, intestine, and testis (Miguel-Queralt et al., 2004). In Atlantic sea bass, northern blot analysis showed that shbga mRNA was strongly expressed in liver but could not be detected in brain, digestive tract, kidney, or gonads (Miguel-Queralt et al., 2007). Using immunocytochemistry, seabass Shbga protein was detected in liver, intestine, and testis. Shbga immunoreactivity was also detected in the connective tissue around the ovary and a positive signal was observed around the post-vitellogenic oocytes of a mature female (Miguel-Queralt et al., 2007). This would be in agreement with the finding of a Shbg-type binding in ovarian interstitial fluids of another perciformes species, the spotted weakfish Cynoscion nebulosus (Laidley and Thomas, 1994). In salmonids, shbga is also strongly expressed in liver (Bobe et al., 2008b;Miguel-

Queralt et al., 2009). In rainbow trout, a strong mRNA expression was also observed in spleen while low expression levels could be detected in gills, stomach, and pituitary using quantitative RT-PCR (Bobe et al., 2008b). In coho salmon, a low expression could also be detected in gills, stomach, and brain (Miguel-Queralt et al., 2009). Together, these data indicate, in agreement with mammalian literature, that liver is the main expression site of Shbga in teleost fish. It is thus likely that the hepatic expression of Shbga, followed by secretion into the blood stream, is resulting in plasma Shbga. This is fully supported by existing data demonstrating that Shbg present in the culture medium of rainbow trout 
hepatocytes and in plasma had similar steroid binding characteristics and electrophoretic mobility (Foucher et al., 1991). However, the significant expression found in several other tissues (e.g. spleen) suggests that, at least in some species, circulating Shbga could also be from extra-hepatic origin. In mammals, a local expression of Shbg in several target organs has also been evidenced and associated with a modulation of the steroidogenic signal (Hryb et al., 2002;Kahn et al., 2002). Similarly, non-hepatic expression sites of Shbga in teleosts could also be associated with local action in target organs. However, further investigation would be necessary in fish to identify potential transcripts variants given that the transcriptional regulation of vertebrate shbg genes could be somewhat complex. For instance, 19 unique transcripts exhibiting differential tissular expression and deriving from 3 different promoters have been recently identified in humans (Nakhla et al., 2009).

In mammals, a protein initially named androgen-binding protein (Abp) due to its binding affinity for androgen was found in the male reproductive tract of several species (Joseph, 1994). Further investigations have however demonstrated, in several mammalian species, that both Shbg and the so-called Abp were in fact encoded by a single copy Shbg gene (Joseph et al., 1987;Hammond et al., 1989;Hammond and Bocchinfuso, 1996). Numerous mammalian studies have further confirmed that testis was an important expression site of Shbg (Selva and Hammond, 2006; Nakhla et al., 2009). In fish, Shbg binding was found in cytosol originating from trout testis that had been previously perfused to avoid blood contamination, in seminal plasma, and in the incubation medium of testicular explants (Foucher and Le Gac, 1989). It was thus hypothesized by these authors that shbg expression could occur in the rainbow trout testis. The binding found in testis was very similar to the binding found in plasma with regards to electrophoretic mobility and relative binding affinity for testosterone (T) and E2 (Foucher and Le Gac, 1989). In contrast, the recombinant Shbgb protein corresponding to the expressed form in the trout ovary has a similar affinity for T and E2 (Bobe et al., 2008b), thus 
suggesting that the testicular Shbg corresponded to Shbga rather than to Shbgb. In agreement with this hypothesis made in trout was the Shbg immunoreactivity observed in zebrafish testis around the seminiferous tubules as well as the testicular expression of shbga mRNA (MiguelQueralt et al., 2004). Surprisingly, no testicular mRNA expression of $s h b g a$ or $s h b g b$ was detected in the two salmonid species investigated so far (Bobe et al., 2008b;Miguel-Queralt et al., 2009). Similarly, no mRNA expression was seen in Atlantic sea bass testis by Northern blot analysis, even though Shbga immunoreactivity could be observed in the interstitial spaces between testicular lobules (Miguel-Queralt et al., 2007). Together, data obtained in fish indicate that testicular expression of shbga mRNA is much lower than what has been evidenced in mammals. In addition, the discrepancy between the lack of testicular shbga expression and the presence of the corresponding Shbga protein observed at least in some species does not rule out uptake and accumulation of it from blood by testicular tissues (Foucher and Le Gac, 1989). Further investigations are required to clarify the expression of shbga gene and corresponding protein in the fish testis.

During development, zebrafish shbga mRNA was detected in larvae 5 and 6 days after fertilization (Miguel-Queralt et al., 2004) while Atlantic sea bass shbga mRNA was detected at all assayed stages between 8 and 150 days post-fertilization (Miguel-Queralt et al., 2007). In both species, it was assumed that the expression occurred in the hepatopancreas or the liver. In mammals, Shbg mRNA is detected as early as 11 days of gestation in rabbit fetal liver and its expression increases dramatically at day 30 to remain high until parturition $(\mathrm{Ng}$ et al., 2005) while the transcript is also detected in fetal rat liver (Sullivan et al., 1991). Together, these available data indicate that shbga expression occurs relatively early during fish development, in agreement to what is observed in some mammals. 


\section{Shbgb}

To date, the tissue distribution of shbgb, the highly divergent paralog of shbga that has only been found in salmonids was only studied in rainbow trout (Bobe et al., 2008b) and, more recently, coho salmon (Miguel-Queralt et al., 2009), two species belonging to the Oncorhynchus genus. In rainbow trout females, a strong ovarian expression was observed while a lower expression was evidenced in muscle and stomach. In contrast, no expression could be detected in brain, pituitary, gills, heart, liver, spleen, intestine, kidney, and skin. Similarly, no expression was found in rainbow trout testis (Bobe et al., 2008b). In coho salmon, the strong ovarian expression of $s h b g b$ mRNA was evidenced in pre-smolt females. A significant expression was also observed in gills, stomach, and muscle. It should however be stressed that differences were observed for these expression sites depending on the sex and the sexual maturity of the fish (Miguel-Queralt et al., 2009). Within the ovary, Shbgb is expressed in the granulosa cells as shown by both in situ hybridization and immunohistochemistry (Bobe et al., 2008b). Based on the binding characteristics of coho salmon Shbga and Shbgb recombinant proteins (Shbga binds androstenedione and ethinylestradiol with high affinity, whereas Shbgb binds E2 preferentially), it was concluded that Shbgb was present in the plasma in both immature and mature fish. However, the protein has never been immunodetected, to date, in salmon or trout plasma. In addition, the estimated amount of Shbgb was much lower than the quantity of Shbga present in the plasma of both pre-smolts and mature fish of both sexes (Miguel-Queralt et al., 2009).

\section{Binding characteristics of Fish Shbg proteins}

The specificity of steroid binding has mostly been investigated in teleost fish. While the amount of information remains limited, available data are consistent with differences in binding characteristics that correspond to the species position in the phylogenetic tree. In 
addition to studies of the proteins in plasma, the binding characteristics of some fish Shbg has been studied in hepatocyte cell culture medium (Foucher et al., 1991), testis extracts (Foucher and Le Gac, 1989), and as recombinant proteins (Miguel-Queralt et al., 2004;Miguel-Queralt et al., 2005;Miguel-Queralt et al., 2009). As discussed above, their characteristics should all correspond to Shbga and are listed in Table 2.

\section{Circulating shbg}

The existence of sex steroids and sex steroid receptors is clearly established in lampreys (Bryan et al., 2008) but to our knowledge, studies on circulating steroid binding proteins are very scarce in these species. Two steroid binding proteins, a $\alpha 1$ and a $\beta$ globulin, have been reported in the sea lamprey (Petromyzon marinus). Both proteins bind progesterone (P4) and E2 but very poorly testosterone (T), the $\alpha 1$ globulin having the highest specificity for P4 and the $\beta$ globulin for E2 (Boffa et al., 1972). They showed lower affinities for T and corticosterone. Further analyses in agnathan species would be valuable due to their evolutionary position in the vertebrate lineage. In gnathostoma, data are unfortunately missing in the primitive ray-finned bony fishes, and to our knowledge, only one preliminary study indicated that testosterone was bound in blood of a chondrostean fish, the Siberian sturgeon (Acipenser baerii, Acipenseriformes) (Bennetau-Pelissero et al., 1998).

Shbg has been, in contrast, characterized in the blood of both chondrichthyes (eslasmobranch: sharks and rays), and osteichtyes (mostly teleostei) (Table 2). Plasma Shbg shows a lower specificity in the first fish group than in the second one since it binds C18 (E2), C19 (T) and $\mathrm{C} 21$ (P4, corticosterone) steroids while $\mathrm{C} 18$ and $\mathrm{C} 19$ steroids are the main steroids able to bind Shbg in teleosts (Freeman and Idler, 1969;Freeman and Idler, 1971;Martin, 1975;Ho et al., 1980). Thus, the dissociation constant of female spiny dogfish plasma for $\mathrm{P} 4(\mathrm{Kd}=23.8$ $\mathrm{nM}$ ) was similar for $\mathrm{T}$ and a little lower than for E2. Furthermore, P4 showed also a similar competition to T against E2 binding for the spiny dogfish testicular Shbg (Mak and Callard, 
1987), while it competed only a little against T binding for the trout testicular Shbg (Foucher and Le Gac, 1989). Furthermore, in almost all studies performed in teleosts, P4 has been shown to be a relatively poor competitor against E2 or T for the circulating Shbga. This is also true for the Shbgb paralog recently found in rainbow trout ovary (Bobe et al., 2008b) and coho salmon blood (Miguel-Queralt et al., 2009). Surprisingly, P4 has been claimed to be a high competitor against E2 in the common carp (Kloas et al., 2000), although the other two studied cyprinidae species, the goldfish, Carassius auratus (Van der Kraak and Biddiscombe, 1999) and the tench, Tinca tinca (Scott et al., 2005), lacked this characteristics.

Species differences in binding affinities are also apparent since osteichtyes show a 5 to 10 fold higher affinity for E2 and T than chondrichthyes, with the exception of Scyliorhinus canicula in which affinity for E2 was similar to teleosts (Martin, 1975). In most teleosts, the dissociation constant for $\mathrm{E} 2$ or $\mathrm{T}$ ranged from 1 to $10 \mathrm{nM}$, which is similar to human $\mathrm{Kd}$ for E2 (Petra et al., 2001). In addition, both association and dissociation rates are rapid in several teleosts, i.e. $\mathrm{t}_{1 / 2}<5$ min (Pasmanik and Callard, 1986;Laidley and Thomas, 1994;Hobby et al., 2000) while the dissociation rate was found to be slower in the spiny dogfish (i.e: $t_{1 / 2}=100$ min). Finally, it should be stressed that a rapid dissociation rate is one of the characteristics classically used to distinguish Shbg proteins from steroid receptors (Table 3).

Differences between studies may be due to methodological discrepancies, especially for the separation of bound and free steroids (Fostier and Breton, 1975) or to the analysis of either complete or partially purified serum (Martin, 1975). Other binding systems, with lower affinities but higher capacities (Cortiscosteroid Binding Globulin like protein, albumin) may exist and interfere in non-purified or non-diluted plasma or serum (Laidley and Thomas, 1994). Thus, blood binding capacities can hardly be compared between species when different methods have been used to estimate bound and unbound steroid fractions (Table 4). For instance, several authors have stressed the possible underestimation of binding capacities due 
to over exposure to dextran-coated charcoal as the separation reagent (DCC) (Foucher and Le Gac, 1989;Laidley and Thomas, 1994;Hobby et al., 2000). Nevertheless, when comparing data obtained with similar methods, estimated Shbg binding capacities for T are close among studied species, including between elasmobranches and teleosts (Table 4). However, differences could also be explained by physiological species specificities depending on natural circulating steroid levels (Laidley and Thomas, 1997; Hobby et al., 2000), or differences between sexual stages, although binding characteristics are generally similar between sexes (Tollefsen et al., 2004). Nutritional factors such as non-esterified fatty acids (Van der Kraak and Biddiscombe, 1999) or environmental estrogens (Tollefsen, 2002) may also modulate Shbg affinity properties.

The progestins 17,20ß-dihydroxy-4-pregnen-3-one (17,20ß-P) and 17,20ß,21-trihydroxy-4pregnen-3-one have a major physiological role in fish as they are involved in teleost oocyte maturation(Bobe et al., 2008a). Interestingly, these progestins compete even less than P4 against E2 or T. However, a dimeric $110 \mathrm{kDa}$ protein able to bind 17,20ß-P has been purified from female rainbow trout plasma (Yoshikuni et al., 1994). Its overall amino acid composition was similar to that of human SHBG, but its binding characteristics were not classical for a Shbg-like protein. Although its affinity for 17,20ß-P appears to be moderate $(\mathrm{Kd}=21 \mathrm{nM}), \mathrm{T}$ and $\mathrm{E} 2 \mathrm{did}$ not compete strongly against 17,20ß-P, showing relative binding affinity values (RBA) of 79 and 31, respectively. Furthermore, 17-hydroxyprogesterone and progesterone had higher and similar RBA than E2; i.e. 65 and 32 respectively. Although salmon Shbga binds progesterone and 17,20ß-P better than Shbgb, this is at a lower level than androgens and estrogens (Table 5). These features do not fit with the properties of other Shbgs and are closer to the binding characteristics of another binding protein found in trout plasma and able to bind C-18, C-19 and C-21 steroids, including some corticosteroids like cortisone (that has not been tested by Yoshikuni et al.) but not cortisol (Fostier and Breton, 
1975). However, the amino acid composition and the dimeric structure of this purified 17,20ß-P binding protein would exclude it from the Cbg protein family. Finally, direct measurement of E2 and T affinities would have been helpful to better compare this protein to other Shbgs.

It is also noteworthy that another physiologically important steroid, 11-ketotestosterone, the fish-specific androgen (Borg, 1994), binds poorly to plasmatic Shbg. Finally, estriol and estrone, which have low biological activity in fish, have also a low affinity for Shbg. Altogether, existing data indicate a specialization of circulating Shbg during evolution towards the preferential binding of E2 and its precursor, T. Both steroids show biological activities in fish. P4 binding, which is still observed in the ovoviviparous elasmobranches, was lost in teleosts. Finally, specific fish steroids as 11-oxo-androgens and oocyte maturationinducing steroids which are actively involved in reproduction are poorly bound by fish Shbg.

\section{Testis Shbg binding}

A counterpart of the mammalian Abp, which is, as indicated above, encoded by a single copy Shbg gene, has been first described in the spiny dogfish (Mak and Callard, 1987). The authors claimed that it was identical to the circulating Shbg in its broad specificity but differed by a longer rate of dissociation $(\mathrm{T} 1 / 2=160 \mathrm{~min} v \mathrm{vs}<30 \mathrm{~min})$ and a faster electrophoretic mobility on polyacrylamide gel. However, such differences were not found for the rainbow trout testicular Shbg which has been found to be secreted by testicular explants (Foucher and Le Gac, 1989). Several Shbg characteristics, especially for tissular Shbg, are classically used for discriminating Shbg binding from T or E2 receptor binding, e.g. higher association and dissociation rates, lower affinity (higher Kd), higher capacity, absence of binding to DNA (Table 3). However, except for the last one, such differences between Shbg and receptors are not always valid as previously stressed (Bryan et al., 2007). 


\section{Shbg recombinant proteins (RPs)}

Binding studies using native purified or recombinant proteins (RP) give the opportunity to perform the characterization of binding features without possible interference due to other binding proteins present in the blood such as Corticosteroid Binding Globulin like protein (Cbg) (Fostier and Breton, 1975) or albumin (Baker, 1998), even though fish Cbg still remains to be further characterized (Mommsen et al., 1999;Fast et al., 2008).

Plasma and RP binding studies (Table 5) gave similar affinity constant estimations in Atlantic sea bass $(\mathrm{Kd}=6.8$ and $8.8 \mathrm{nM}$, respectively; (Miguel-Queralt et al., 2005) and similar electrophoretic mobilities in Atlantic sea bass and zebrafish (Miguel-Queralt et al., 2004). Interestingly, in salmonids, RPs have been used to specifically characterize the two Shbg forms (Bobe et al., 2008b;Miguel-Queralt et al., 2009). Altogether, data interpretation is made difficult by the diversity of tritiated steroids used to estimate affinity constants and relative binding affinities. E2 and T show high affinities for both Shbga and Shbgb with a possible higher affinity of Shbgb for E2. In contrast, estriol, cortisol and progestins have low or very low affinities. Androstenedione (A4), 5 $\alpha$-dihydrotestosterone (DHT), $17 \alpha$-ethynyl-estradiol and, to a lesser extent, estrone and 11-ketotestosterone show a higher affinities for Shbga than for Shbgb. Finally, Shbgb binds 2-methoxy-estradiol with a higher affinity than Shbga.

\section{Binding to xenobiotics}

The potential binding of xenobiotics to Shbg is of particular interest because that could be a mechanism of disturbing action for these molecules. Concerning pharmaceutical steroids, 17a-ethynylestradiol and diethylstilbestrol showed low or high affinity for Shbg depending on the species, but other xenobiotics like phytotoxins, pesticides and industrial estrogenic compounds compete poorly for Shbg E2 binding (McPherson et al., 1988;Milligan et al., 1998;Tollefsen et al., 2004;Miguel-Queralt et al., 2005). However, these compounds could 
interfere with native steroid binding to Shbg because they may be found at high concentrations (Milligan et al., 1998). Estrogenic pollutants could thus modulate Shbg synthesis by the liver and change the blood binding capacities (Pryce-Hobby et al., 2003). Interestingly, a recent study explored the possibility to screen in silico the binding potentialities of 80,000 commercial chemicals listed by the European Chemical Bureau and Environment Canada by using a zebrafish Shbg model (Thorsteinson et al., 2009). Six nonsteroidal substances of the top hits were shown to displace effectively ${ }^{3} \mathrm{H}-5 \alpha$-DHT bound to a zebrafish recombinant Shbga, and three of them bound in the micromolar range.

\section{Putative functional roles of Shbg proteins}

As in mammals, fish Shbg proteins are considered to be involved in sex steroid transport, regulation, and action. However, to our knowledge, no study in fish is clearly showing a direct action of Shbg on specific biological mechanisms. In addition, circulating Shbg has received most of the attention so far, but it may be reasonably hypothesized that the function of this circulating form, or forms, could be very different from the functions of Shbg proteins expressed locally in target organs and tissues.

\section{Protective and transport functions of Shbg}

Shbg-type binding fluctuated in blood in parallel to sex steroids levels in spotted weakfish (Laidley and Thomas, 1997) and Indian major carp, Labeo rohita (Suresh et al., 2008) but not in common carp (Chang and Chen, 1990) and brown trout, Salmo trutta (Pottinger, 1988). A direct relationship may be due to the stimulation of liver Shbg synthesis by E2 (Foucher et al., 1991). However, when studied in details in spotted weakfish, no significant correlation could be found between Shbg binding and E2 or T plasma levels (Laidley and Thomas, 1997). In contrast, the hypothesis of a protective role of Shbg for biologically active plasma steroids would be consistent with Shbg binding characteristics found in teleosts and elasmobranches. 
As already known, E2 and T have a peripheral action in both Elasmobranches and Teleosts and are both able to bind Shbg. In contrast, ovarian progestins have mainly a local action in teleosts (Bobe et al., 2008a) while P4 has a peripheral action in Elasmobranches. Indeed, it can be noted that Elasmobranch Shgb can bind P4 (Jones and Baxter, 1991) while Shbg has very little affinity for progestins in teleosts species (Table 5). Thus, the associated loss of both Shbg binding and peripheral action of progestins during evolution would be in favor of a major protective and transport role of Shbg for plasma steroids.

As evidenced in Atlantic sea bass, circulating Shbga levels decrease in both males and females during reproductive season (Miguel-Queralt et al., 2007). Similarly, circulating Shbg levels decrease in male rainbow trout towards the end of the reproductive cycle, e.g. during spermiation (Foucher et al., 1992) and the plasma-binding capacity of both mature and immature brown trout declined during the spawning period (Pottinger, 1988). Such a decrease in blood E2 at the end of the female cycle (Fostier et al., 1978;Goetz et al., 1987;Bobe et al., 2003) is necessary for the completion vitellogenesis but also to release an E2 inhibition on the maturation inducing steroid synthesis by granulosa, as shown in rainbow trout (Jalabert and Fostier, 1984a;Jalabert and Fostier, 1984b;Fostier and Baek, 1993). Such blood E2 decrease is related to the decrease of ovarian aromatase activity (Young et al., 1983) and gene expression (cyp19ala) (Bobe et al., 2008b), but is amplified also by a higher metabolic clearance of E2 (Baroiller et al., 1987). This higher clearance could be due to a decrease of Shbg-protected E2 levels. In conclusion, blood Shbg might play a major role in fish for the regulation of E2 and T catabolism since binding capacities reach levels (110-3500 nM; Table 4) sufficient to bind a large part, if not all, of the circulating sex steroids (roughly in the range of 3 to $300 \mathrm{nM}$, according to sexual stages and species). However, the protective function of Shbg against steroid catabolism is not completely accepted. After comparing radioactive steroids affinities for tench Shbg and their clearances, which have been estimated by the accumulation of their 
radioactivity in the gale bladder, it was suggested that Shbg could enhance the ability of the steroid to be metabolized by the liver (Scott et al., 2005). In fact, peripheral metabolization of steroids is a multi-compartments system in which metabolizing enzymes levels and affinities, with their own regulation, have to be taken into account. Shbg should be considered only as a part of this complex system.

\section{Facilitation of liphophilic steroid release into the environment}

In fish, the regulation of steroid metabolism and excretion in the aquatic environment has a particular biological significance because some free and conjugated steroids play an important pheromonal role in both males and females (Stacey et al., 2003). Hydrophilic conjugated steroid are not bound by Shbg (Hobby et al., 2000;Tollefsen, 2002) and can be release freely into urine. Interestingly, no significant shbga or shbgb expression could be detected in the kidney, as indicated above. In contrast, liphophilic non-conjugated steroidal pheromones can be released by the gills (Vermeirssen and Scott, 1996) and Shbg may regulate their diffusion (or uptake) between water and blood through the gill membranes, depending on their affinities for the protein (Scott et al., 2005). Considering a protective function of Shbg, the protein might also help in providing unmetabolized active steroids to the fish environment. These various functions need to be provided at the gills level and Shbg, which has been found to be expressed in gills, could have such local physiological functions, regardless of its potentiality to uptake xenobiotics from the aquatic environment (Miguel-Queralt and Hammond, 2008).

At the local ovarian level, salmonid shbgb and cyp19ala are expressed in the same follicular compartment, the granulosa layer, as shown by in situ hybridization in trout (Bobe et al., 2008b) and the exchange of $\mathrm{T}$ and E2 between Shbg and the aromatase enzyme is worth considering. As suggested by Pasmanik and Callard (1986), aromatase and Shbg affinities for $\mathrm{T}$ are close (aromatase $\mathrm{Km}$ usually in the range 5-50 $\mathrm{nM}$ according to Piferrer.and Blazquez, 2005), thus facilitating the transfer of T from Shbg to the enzyme. After T aromatization, E2 
may be quickly bound by Shbg for a protected transportation to its targets. In that case, a cellular local couple Shbgb-Aromatase might be a fully functional system to maintain a proper E2 production. Together, these observations suggest a local participation of Shbgb in steroidogenesis and/or steroid action during late oogenesis in salmonids, possibly in follicleenclosed maturational competence acquisition. Given the remarkably high levels of brain aromatase found in fish (Piferrer and Blazquez, 2005), the transfer of $\mathrm{T}$ to aromatase might also occur in pituitary and brain where Shbga transcripts have been found to be expressed in salmonids (Bobe et al., 2008b; Miguel-Queralt et al., 2009).

\section{Shbga Shbgb and tissular receptors: 3 actors involved in E2/T availability}

Finally, a finely tuned equilibrium may also occur, in teleosts, for E2 and $\mathrm{T}$ between circulating or local Shbg and their nuclear or membrane receptors. In fact, affinities of E2 and $\mathrm{T}$ for their receptors are close to their affinities for Shbg (Table 3) and range from 1 to $5 \mathrm{nM}$ (Lazier et al., 1985;McPherson et al., 1988;Pottinger and Pickering, 1990;Kloas et al., 2000;Tollefsen et al., 2002;Gale et al., 2004; Thomas et al., 2006).

\section{Conclusion}

In fish, two different genes, shbga and shbgb, exist that encode for Shbga and Shbgb proteins respectively. Shbga is the ortholog of mammalian Shbg and has been found in all teleost species investigated thus far. In contrast, Shbgb has only been characterized from salmonid species and it remains unclear whether or not this highly divergent paralog results from salmonid-specific duplication or from a more ancient duplication followed by a subsequent loss in all non-salmonid vertebrate species. The genomic sequences obtained from species with an available genome sequence suggest that shbga genomic organization is well conserved in teleosts. In contrast, the genomic sequence of shbgb remains currently unknown. 
Shbga is mainly expressed in the liver where it is subsequently secreted into the blood. Other important sites of Shbga expression exist that could also contribute to plasma Shbga levels and/or support a local function of this protein in target organs. In contrast, Shbgb is mainly expressed in the ovary where it could contribute to the regulation of local steroid action. In coho salmon, Shbgb is expressed in both males and females and is also detected in plasma, thus suggesting possible species-specific differences among salmonids.

In the blood of sea lamprey, an agnathan vertebrate that occupies a key phylogenetic position between cephalochordates and gnathostomes, two globulins are able to bind E2 and P4, but not $\mathrm{T}$. Testosterone binding is established in elasmobranches and is maintained in teleosts while P4 binding, which is still observed in elasmobranches, was lost in teleosts. Altogether, existing binding studies indicate a specialization of circulating Shbg during evolution towards a preferential and more specific binding of E2 and its precursor, T. As previously stressed, specific fish steroids such as 11-oxo-androgens and oocyte maturation-inducing steroids which are actively involved in reproduction are poorly bound by Shbg. In addition, several bodies of evidence indicate that circulating Shbg might play a major role in the regulation of E2 and T transport and availability for metabolization or target organs, as binding capacities reach levels sufficient to bind a large part, if not all, of the circulating sex steroids in investigated fish species.

Further studies are needed to better understand the evolutionary history of Shbg proteins in vertebrates. This is especially true for the salmonid-specific Shbgb form. New insights in the local expression and potential action of both Shbga and Shbgb protein in target organs are also required to better understand the biological significance of each protein and the possible contribution of the non-hepatic expression sites to circulating Shbga, and possibly Shbgb, levels. In addition, the striking dynamic co-expression of cyp19ala and shbgb in the rainbow trout ovarian follicle during late oogenesis raises the question of the participation of Shbgb in 
some key steps of fish reproduction, in which E2 plays a key role. In the light of existing mammalian literature on the local role of Shbg in target organs, this suggests a possible participation of Shbg in the local modulation of reproductive functions by steroids that will require future investigations.

\section{References}

Allendorf, F.W., Thorgaard, G.H., 1984. Tetraploidy and the evolution of salmonid fishes. In: Turner, B.J. (Ed.), The Evolutionary Genetics of Fishes Plenum Press, New York, pp. 1-53.

Avvakumov, G.V., Grishkovskaya, I., Muller, Y.A., Hammond, G.L., 2001. Resolution of the human sex hormone-binding globulin dimer interface and evidence for two steroid-binding sites per homodimer. J. Biol. Chem. 276, 34453-34457.

Baker, M.E., 1998. Albumin's role in steroid hormone action and the origins of vertebrates: is albumin an essential protein? FEBS Lett. 439, 9-12.

Baroiller, J.F., Fostier, A., Zohar, Y., Marcuzzi, O., 1987. The metabolic clearance rate of estradiol-17 beta in rainbow trout, Salmo gairdneri R., estimated by both single injection and constant infusion methods: increase during oocyte maturation. Gen. Comp. Endocrinol. 66, 85-94.

Bennetau-Pelissero, C., Kaushik, S., Sumpter, J.P., Fostier, A., Le Gac, F., Valotaire, Y., Davail-Cuisset, B., Le Menn, F., 1998. Effets du soja et des phyto-oestrogènes sur la vitellogénèse et l'endocrinologie de la truite arc-en-ciel et de l'esturgeon sibérien. Approches in vivo et in vitro. Bulletin Français de la Pêche et Pisciculture 350-351, 571-583.

Bobe, J., Jalabert, B., Fostier, A., 2008a. Oogenesis: post-vitellogenic events leading to a fertilizable oocyte. In: Rocha, M.J., Arukwe, A., Kapoor, B.G. (Eds.), Fish Reproduction Science Publishers, Enfield, pp. 1-36.

Bobe, J., Mahe, S., Nguyen, T., Rime, H., Vizziano, D., Fostier, A., Guiguen, Y., 2008b. A novel, functional, and highly divergent Sex Hormone-Binding Globulin that may participate in the local control of ovarian functions in salmonids. Endocrinology 149, 2980-2989.

Bobe, J., Maugars, G., Nguyen, T., Jalabert, B., 2003. Specific gene expression profiles are associated with follicular maturational competence acquisition in rainbow trout (Oncorhynchus mykiss). Fish Physiology and Biochemistry 28, 309-311.

Bocchinfuso, W.P., Ma, K.L., Lee, W.M., Warmels-Rodenhiser, S., Hammond, G.L., 1992. Selective removal of glycosylation sites from sex hormone-binding globulin by site-directed mutagenesis. Endocrinology 131, 2331-2336.

Boffa, G.A., Martin, B., Winchenne, J.J., Ozon, R., 1972. Interactions stéroïdes-protéines dans le sérum de l'homme, d'un amphibien et d'un cyclostome. Biochimie 54, 1137-1145. 
Borg, B., 1994. Androgens in teleost fishes. Comp. Biochem. Physiol. C. 109, 219-245.

Bryan, M.B., Scott, A.P., Li, W., 2007. The sea lamprey (Petromyzon marinus) has a receptor for androstenedione. Biol. Reprod. 77, 688-696.

Bryan, M.B., Scott, A.P., Li, W., 2008. Sex steroids and their receptors in lampreys. Steroids 73, 1-12.

Callard, G.V., Mak, P., 1985. Exclusive nuclear location of estrogen receptors in Squalus testis. Proc. Natl. Acad. Sci U. S. A 82, 1336-1340.

Chang, C.F., Chen, M.R., 1990. Fluctuation in sex steroids and sex steroid-binding protein during the development and annual cycle of the male common carp, Cyprinus carpio. Comp. Biochem. Physiol. 97A, 565-568.

Chang, C.F., Lee, Y.H., 1992. Purification of the sex steroid-binding protein from common carp (Cyprinus carpio) plasma. Comp Biochem. Physiol B 101, 587-590.

Chang, C.F., Lee, Y.H., Yoshida, T., Sun, L.T., 1994. Characterization of the plasma sex steroid-binding protein in eel (Anguilla japonica). Comp. Biochem. Physiol. B. Biochem. Mol. Biol. 108B, 189-197.

Cousin, P., Dechaud, H., Grenot, C., Lejeune, H., Hammond, G.L., Pugeat, M., 1999. Influence of glycosylation on the clearance of recombinant human sex hormone-binding globulin from rabbit blood. J. Steroid Biochem. Mol. Biol. 70, 115-121.

Danzo, B.J., Black, J.H., Bell, B.W., 1989. The microheterogeneity of rabbit testosteronebinding globulin is due to differential glycosylation of its single protomer. Biol. Reprod. 41, 957-965.

Delsuc, F., Brinkmann, H., Philippe, H., 2005. Phylogenomics and the reconstruction of the tree of life. Nat Rev Genet 6, 361-375.

Fast, M.D., Hosoya, S., Johnson, S.C., Afonso, L.O., 2008. Cortisol response and immunerelated effects of Atlantic salmon (Salmo salar Linnaeus) subjected to short- and long-term stress. Fish Shellfish. Immunol. 24, 194-204.

Fostier, A., Baek, H., 1993. Inhibition of production of maturation inducing steroid in rainbow trout granulosa cells : effect of oestradiol on gonadotropin stimulated 20-betahydroxysteroid dehydrogenase activity. Reprod. Nutr. Dev. 33, 81-82.

Fostier, A., Breton, B., 1975. Binding of steroids by plasma of a teleost: the rainbow trout, Salmo gairdneri. J Steroid Biochem 6, 345-51.

Fostier, A., Weil, C., Terqui, M., Breton, B., Jalabert, B., 1978. Plasma estradiol 17 beta and gonadotropin during ovulation in rainbow trout Salmo Gairdneri. Ann. Biol. Anim. Biochim. Biophys. 18, 929-936.

Foucher, J.L., Le Bail, P.Y., Le Gac, F., 1992. Influence of hypophysectomy, castration, fasting, and spermiation on SBP concentration in male rainbow trout (Oncorhynchus mykiss). Gen. Comp Endocrinol. 85, 101-110. 
Foucher, J.L., Le Gac, F., 1989. Evidence for an androgen binding protein in the testis of a teleost fish (Salmo gairdneri R.): a potential marker of Sertoli cell function. J. Steroid Biochem. 32, 545-552.

Foucher, J.L., Niu, P.D., Mourot, B., Vaillant, C., Le Gac, F., 1991. In vivo and in vitro studies on sex steroid binding protein (SBP) regulation in rainbow trout (Oncorhynchus mykiss): influence of sex steroid hormones and of factors linked to growth and metabolism. J. Steroid Biochem. Mol. Biol. 39, 975-986.

Freeman, H.C., Idler, D.R., 1969. Sex hormone binding proteins. II. Isolation from serum of an elasmobranch (Raja radiata). Gen. Comp Endocrinol. 13, 83-91.

Freeman, H.C., Idler, D.R., 1971. Binding affinities of blood protens for sex hormones and corticosteroids in fish. Steroids 17, 233-250.

Gale, W.L., Patino, R., Maule, A.G., 2004. Interaction of xenobiotics with estrogen receptors alpha and beta and a putative plasma sex hormone-binding globulin from channel catfish (Ictalurus punctatus). Gen. Comp Endocrinol. 136, 338-345.

Goetz, F.W., Fostier, A.Y., Breton, B., Jalabert, B., 1987. Hormonal changes during meiotic maturation and ovulation in the brook trout (Salvelinus fontinalis). Fish Physiology and Biochemistry 3, 203-211.

Gouret, P., Vitiello, V., Balandraud, N., Gilles, A., Pontarotti, P., Danchin, E.G., 2005. FIGENIX: intelligent automation of genomic annotation: expertise integration in a new software platform. BMC. Bioinformatics. 6, 198.

Hammond, G.L., Bocchinfuso, W.P., 1996. Sex hormone-binding globulin: gene organization and structure/function analyses. Horm. Res. 45, 197-201.

Hammond, G.L., Underhill, D.A., Rykse, H.M., Smith, C.L., 1989. The human sex hormonebinding globulin gene contains exons for androgen-binding protein and two other testicular messenger RNAs. Mol. Endocrinol. 3, 1869-1876.

Ho, S.M., Tsang, P., Callard, I.P., 1980. Some properties of a steroid-binding protein in the plasma of an ovoviviparous dogfish, Squalus acanthias, at different stages of the life cycle. Biol. Reprod. 23, 281-289.

Hobby, A.C., Geraghty, D.P., Pankhurst, N.W., 2000. Differences in binding characteristics of sex steroid binding protein in reproductive and nonreproductive female rainbow trout (Oncorhynchus mykiss), black bream (Acanthopagrus butcheri), and greenback flounder (Rhombosolea tapirina). Gen. Comp Endocrinol. 120, 249-259.

Hryb, D.J., Nakhla, A.M., Kahn, S.M., St George, J., Levy, N.C., Romas, N.A., Rosner, W., 2002. Sex hormone-binding globulin in the human prostate is locally synthesized and may act as an autocrine/paracrine effector. J. Biol. Chem. 277, 26618-26622.

Jalabert, B., Fostier, A., 1984a. The follicular sensitivity in vitro to maturation-inducing hormones in rainbow trout, Salmo gairdneri: role of oestradiol-17 $\beta$. Aqua 43, 1-11.

Jalabert, B., Fostier, A., 1984b. The modulatory effect in vitro of oestradiol-17 $\beta$, testosterone or cortisol on the output of $17 \alpha$-hydroxy-20 $\beta$-dihydroprogesterone by rainbow trout (Salmo 
gairdneri) ovarian follicles stimulated by the maturational gonadotropin s-GtH. Reprod Nutr Develop 24, 127-136.

Jones, R.E., Baxter, D.C., 1991. Gestation, with emphasis on corpus luteum biology, placentation, and parturition. In: Pang, P.K.T., Schreibman, M.P. (Eds.), Vertebrate endocrinology: fundamentals and biomedical implications Academic Press, pp. 205-302.

Joseph, D.R., 1994. Structure, function, and regulation of androgen-binding protein/sex hormone-binding globulin. Vitam. Horm. 49, 197-280.

Joseph, D.R., Hall, S.H., French, F.S., 1987. Rat androgen-binding protein: evidence for identical subunits and amino acid sequence homology with human sex hormone-binding globulin. Proc. Natl. Acad. Sci. U. S. A 84, 339-343.

Joseph, D.R., Sullivan, P.M., Wang, Y.M., Millhorn, D.E., Bayliss, D.M., 1991. Complex structure and regulation of the ABP/SHBG gene. J Steroid Biochem. Mol. Biol 40, 771-775.

Kahn, S.M., Hryb, D.J., Nakhla, A.M., Romas, N.A., Rosner, W., 2002. Sex hormone-binding globulin is synthesized in target cells. J. Endocrinol. 175, 113-120.

Khan, M.S., Hryb, D.J., Hashim, G.A., Romas, N.A., Rosner, W., 1990. Delineation and synthesis of the membrane receptor-binding domain of sex hormone-binding globulin. J. Biol. Chem. 265, 18362-18365.

Kloas, W., Schrag, B., Ehnes, C., Segner, H., 2000. Binding of xenobiotics to hepatic estrogen receptor and plasma sex steroid binding protein in the teleost fish, the common carp (Cyprinus carpio). Gen. Comp Endocrinol. 119, 287-299.

Laidley, C.W., Thomas, P., 1994. Partial characterization of a sex-steroid binding protein in the spotted seatrout (Cynoscion nebulosus). Biol. Reprod. 51, 982-992.

Laidley, C.W., Thomas, P., 1997. Changes in plasma sex steroid-binding protein levels associated with ovarian recrudescence in the spotted seatrout (Cynoscion nebulosus). Biol. Reprod. 56, 931-937.

Larhammar, D., Risinger, C., 1994. Molecular genetic aspects of tetraploidy in the common carp Cyprinus carpio. Mol. Phylogenet. Evol. 3, 59-68.

Lazier, C.B., Lonergan, K., Mommsen, T.P., 1985. Hepatic estrogen receptors and plasma estrogen-binding activity in the Atlantic salmon. Gen. Comp Endocrinol. 57, 234-245.

Mak, P., Callard, G.V., 1987. A novel steroid-binding protein in the testis of the dogfish Squalus acanthias. Gen. Comp Endocrinol. 68, 104-112.

Martin, B., 1975. Steroid-protein interactions in nonmammalian vertebrates. I. Elasmobranch steroids-binding protein (E. SBP) in dogfish serum (Scyliorhinus canicula). Gen. Comp Endocrinol. 25, 42-51.

McPherson, R., Hannum, J., Greco, T., 1988. An investigation of an estrogen-binding component in the liver and plasma of brook char, Salvelinus fontinalis. Comp Biochem. Physiol A Comp Physiol 89, 615-619. 
Miguel-Queralt, S., Avvakumov, G.V., Blazquez, M., Piferrer, F., Hammond, G.L., 2005. Sea bass (Dicentrarchus labrax) sex hormone binding globulin: molecular and biochemical properties and phylogenetic comparison of its orthologues in multiple fish species. Mol. Cell Endocrinol. 229, 21-29.

Miguel-Queralt, S., Blazquez, M., Piferrer, F., Hammond, G.L., 2007. Sex hormone-binding globulin expression in sea bass (Dicentrarchus labrax L.) throughout development and the reproductive season. Mol. Cell Endocrinol. 276, 55-62.

Miguel-Queralt, S., Hammond, G.L., 2008. Sex hormone-binding globulin in fish gills is a portal for sex steroids breached by xenobiotics. Endocrinology 149, 4269-4275.

Miguel-Queralt, S., Knowlton, M., Avvakumov, G.V., Al Nouno, R., Kelly, G.M., Hammond, G.L., 2004. Molecular and functional characterization of sex hormone binding globulin in zebrafish. Endocrinology 145, 5221-5230.

Miguel-Queralt, S., Underhill, C., Devlin, R.H., Hammond, G.L., 2009. Characterization and measurement of the plasma alpha- and beta-sex hormone-binding globulin paralogs in salmon. Endocrinology 150, 366-375.

Milligan, S.R., Khan, O., Nash, M., 1998. Competitive binding of xenobiotic oestrogens to rat alpha-fetoprotein and to sex steroid binding proteins in human and rainbow trout (Oncorhynchus mykiss) plasma. Gen. Comp Endocrinol. 112, 89-95.

Mommsen, T., Vijayan, M.M., Moon, T.W., 1999. Cortisol in teleosts: dynamics, mechanisms of action, and metabolic regulation. Reviews in Fish Biology and Fisheries 9, 211-268.

Nakhla, A.M., Hryb, D.J., Rosner, W., Romas, N.A., Xiang, Z., Kahn, S.M., 2009. Human sex hormone-binding globulin gene expression- multiple promoters and complex alternative splicing. BMC. Mol. Biol. 10, 37.

Ng, K.M., So, M.T., Lee, W.M., 2005. Expression of rabbit sex hormone-binding globulin during pregnancy and prenatal development and identification of a novel isoform.

Endocrinology 146, 1965-1972.

Pasmanik, M., Callard, G., 1986. Characteristics of a testosterone-estradiol binding globulin (TEBG) in goldfish serum. Biol. Reprod. 35, 838-845.

Petra, P.H., Adman, E.T., Orr, W.R., Woodcock, K.T., Groff, C., Sui, L.M., 2001. Arginine140 and isoleucine-141 determine the 17beta-estradiol-binding specificity of the sex-steroidbinding protein (SBP, or SHBG) of human plasma. Protein Sci 10, 1811-1821.

Piferrer, F., Blazquez, M., 2005. Aromatase distribution and regulation in fish. Fish Physiology and Biochemistry 31, 215-226.

Pottinger, T.G., 1988. Seasonal variation in specific plasma- and target-tissue binding of androgens, relative to plasma steroid levels, in the brown trout, Salmo trutta L. Gen. Comp Endocrinol. 70, 334-344. 
Pottinger, T.G., Pickering, A.D., 1990. The effect of cortisol administration on hepatic and plasma estradiol-binding capacity in immature female rainbow trout (Oncorhynchus mykiss). Gen. Comp Endocrinol. 80, 264-273.

Pryce-Hobby, A.C., McMaster, M.E., Hewitt, L.M., Van Der, K.G., 2003. The effects of pulp mill effluent on the sex steroid binding protein in white sucker (Catostomus commersoni) and longnose sucker (C catostomus). Comp Biochem. Physiol C Toxicol. Pharmacol. 134, 241250 .

Querat, B., Hardy, A., Leloup-Hatey, J., 1983. Etude de la liaison plasmatique des stéroïdes sexuels et du cortisol chez l'anguille femelle (Anguilla anguilla L.). Comptes Rendus de l'Académie des Sciences, série III 297, 119-122.

Rosner, W., 2006. Sex steroids and the free hormone hypothesis. Cell 124, 455-456.

Rosner, W., Christy, N.P., Kelly, W.G., 1969. Partial purification and preliminary characterization of estrogen-binding globulins from human plasma. Biochemistry (Mosc). 8, 3100-3108.

Scott, A.P., Pinillos, M.L., Huertas, M., 2005. The rate of uptake of sex steroids from water by Tinca tinca is influenced by their affinity for sex steroid binding protein in plasma. Journal of Fish Biology 67, 182-200.

Selva, D.M., Hammond, G.L., 2006. Human sex hormone-binding globulin is expressed in testicular germ cells and not in sertoli cells. Horm. Metab Res. 38, 230-235.

Stacey, N.E., Chojnacki, A., Narayanan, A., Cole, T.B., Murphy, C.A., 2003. Hormonally derived sex pheromones in fish: exogenous cues and signals from gonad to brain. Can. J. Physiol. Pharmacol. 81, 329-341.

Steinke, D., Salzburger, W., Braasch, I., Meyer, A., 2006. Many genes in fish have speciesspecific asymmetric rates of molecular evolution. BMC. Genomics 7, 20.

Sullivan, P.M., Petrusz, P., Szpirer, C., Joseph, D.R., 1991. Alternative processing of androgen-binding protein RNA transcripts in fetal rat liver. Identification of a transcript formed by trans splicing. J Biol Chem. 266, 143-154.

Suresh, D.V., Baile, V.V., Prasada Rao, P.D., 2008. Annual reproductive phase-related profile of sex steroids and their carrier, SHBG, in the Indian major carp, Labeo rohita. Gen. Comp Endocrinol. 159, 143-149.

Thomas, P., Dressing, G., Pang, Y., Berg, H., Tubbs, C., Benninghoff, A., Doughty, K., 2006. Progestin, estrogen and androgen G-protein coupled receptors in fish gonads. Steroids 71, 310-316.

Thorsteinson, N., Ban, F., Santos-Filho, O., Tabaei, S.M., Miguel-Queralt, S., Underhill, C., Cherkasov, A., Hammond, G.L., 2009. In silico identification of anthropogenic chemicals as ligands of zebrafish sex hormone binding globulin. Toxicol. Appl. Pharmacol. 234, 47-57.

Tollefsen, K.E., 2002. Interaction of estrogen mimics, singly and in combination, with plasma sex steroid-binding proteins in rainbow trout (Oncorhynchus mykiss). Aquat. Toxicol. 56, 215-225. 
Tollefsen, K.E., Meys, J.F., Frydenlund, J., Stenersen, J., 2002. Environmental estrogens interact with and modulate the properties of plasma sex steroid-binding proteins in juvenile Atlantic salmon (Salmo salar). Mar. Environ. Res. 54, 697-701.

Tollefsen, K.E., Ovrevik, J., Stenersen, J., 2004. Binding of xenoestrogens to the sex steroidbinding protein in plasma from Arctic charr (Salvelinus alpinus L.). Comp Biochem. Physiol C Toxicol. Pharmacol. 139, 127-133.

Van der Kraak, G., Biddiscombe, S., 1999. Polyunsaturated fatty acids modulate the properties of the sex steroid binding protein in goldfish. Fish Physiology and Biochemistry $20,115-123$.

Vermeirssen, E.L., Scott, A.P., 1996. Excretion of free and conjugated steroids in rainbow trout (Oncorhynchus mykiss): evidence for branchial excretion of the maturation-inducing steroid, 17,20 beta-dihydroxy-4-pregnen-3-one. Gen. Comp Endocrinol. 101, 180-194.

Yoshikuni, M., Matsushita, H., Shibata, N., Nagahama, Y., 1994. Purification and characterization of 17 alpha,20 beta-dihydroxy-4-pregnen-3-one binding protein from plasma of rainbow trout, Oncorhynchus mykiss. Gen. Comp Endocrinol. 96, 189-196.

Young, G., Kagawa, H., Nagahama, Y., 1983. Evidence for a decrease in aromatase activity in the ovarian granulosa cells of amago salmon (Oncorhynchus rhodurus) associated with final oocyte maturation. Biol. Reprod. 29, 310-315. 
Tables

Table 1. Cross-species amino acid sequence identities (in \% of identity) among vertebrate

Shbg proteins.

\begin{tabular}{|c|c|c|c|c|c|c|c|c|}
\hline & & \multicolumn{5}{|c|}{ Fish Shbga } & SHBG & Shbgb \\
\hline & Species & D. rerio & C. carpio I & C. carpio II & O. mykiss & D. labrax & H. sapiens & O. mykiss \\
\hline \multirow{5}{*}{ 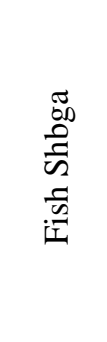 } & D. rerio & 100 & 86.3 & 80.2 & 51.8 & 42 & 25.9 & 21.2 \\
\hline & C. carpio I & 86.3 & 100 & 88 & 51.4 & 42.5 & 26.5 & 21.6 \\
\hline & C. carpio II & 80.2 & 88 & 100 & 49.3 & 39.9 & 24.6 & 20.7 \\
\hline & O. mykiss & 51.8 & 51.4 & 49.3 & 100 & 50.1 & 27.7 & 20.8 \\
\hline & D. labrax & 42 & 42.5 & 39.9 & 50.1 & 100 & 25.6 & 22 \\
\hline SHBG & H. sapiens & 25.9 & 26.5 & 24.6 & 27.7 & 25.6 & 100 & 19.8 \\
\hline Shbgb & O. mykiss & 21.2 & 21.6 & 20.7 & 20.8 & 22 & 19.8 & 100 \\
\hline
\end{tabular}


Table 2. Shbg binding characteristics in gnathostoma fish. The sex and sexual stage (M: mature, IMM: immature) are indicated.

(1) Samples used for the binding studies might be serum, plasma, a partially purified fraction (P.P.F) or a recombinant protein (R.P.). Various methods might be used to separate bound and free steroids, i.e. equilibrium dialysis (Dial.), gel filtration (GF), DEAE (gel of filter), dextran-coated charcoal (DCC). Temperature at which incubation was performed separation is mentioned. The duration of incubations were usually $16 \mathrm{~h}$ or 'overnight'.

(2) Except when indicated, Relative binding affinity values (RBA) are estimated by the ratio of the concentration of radioinert T, E2 or DHT to those of tested steroids resulting in a 50\% reduction in the specific binding of tritiated T, E2 or DHT.

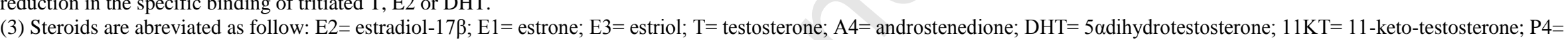
progesterone; $17,20 \mathrm{P}=17,20 \beta$-dihydroxy-4-pregnen-3-one; $20 \beta \mathrm{S}=17,20 \beta, 21$-trihydroxy-4-pregnen-3-one; $\mathrm{F}=$ cortisol

(4) These values are non competitive binding relative to testosterone $=\%$ bound of $0.1 \mu \mathrm{M}$ (Idler and Freeman, 1969) or $0.1 \mu \mathrm{M}$ (Freeman and Idler, 1969) of cold steroid / \% bound of the same concentration of cold $\mathrm{T}$.

(5) In that case, $100 \mathrm{ng}$ of displacing steroid has been used in competition with $0.1 \mathrm{ng}{ }^{3} \mathrm{H}-$-testosterone.

(6) The relative ability of various steroid to displace ${ }^{3} \mathrm{H}-\mathrm{T},{ }^{3} \mathrm{H}-\mathrm{E} 2$ or ${ }^{3} \mathrm{H}-\mathrm{P} 4$ has been estimated by the only competition of competing steroid at the concentration of $1 \times 10^{-7} \mathrm{M}$ against ${ }^{3} \mathrm{H}$-steroid at the concentration of $1.2-1.7 \times 10^{-10} \mathrm{M}$

(7) These values have not been given by the authors but have been roughly estimated according to their graphical data in order to indicate the rank of competition.

(8) RBA was estimated from the estimated Kd of each competing steroid relatively to E2 Kd.

(9) The relative ability of various steroid to displace ${ }^{3} \mathrm{H}-\mathrm{T},{ }^{3} \mathrm{H}-\mathrm{E} 2$ or ${ }^{3} \mathrm{H}-\mathrm{P} 4$ has been estimated by the only competition of competing steroid at the concentration of $2 \mathrm{x} 10^{-7} \mathrm{M}$ against ${ }^{3} \mathrm{H}$-steroid at the concentration of $2 \times 10^{-9} \mathrm{M}$.

(10) Media of primary culture of hepatocytes 


\begin{tabular}{|c|c|c|c|c|c|c|c|c|c|c|c|c|c|c|c|c|c|}
\hline \multirow{4}{*}{$\begin{array}{c}\text { CLASS Order } \\
\text { Species }\end{array}$} & \multirow{4}{*}{$\begin{array}{l}\text { Sample and } \\
\text { method }^{(1)}\end{array}$} & \multirow{4}{*}{ Sex } & \multirow{4}{*}{$\begin{array}{l}\text { Sexual } \\
\text { stage }\end{array}$} & \multirow{2}{*}{\multicolumn{2}{|c|}{$\mathbf{K d}(\mathbf{n M})$}} & \multicolumn{11}{|c|}{ Relative Binding Affinities ${ }^{(2)}$} & \multirow{4}{*}{ References } \\
\hline & & & & & & \multirow{3}{*}{$\begin{array}{l}\text { Bound } \\
{ }^{3} \mathrm{H}-\mathrm{St}\end{array}$} & \multicolumn{10}{|c|}{ Competitive steroids against ${ }^{3} \mathrm{H}-\mathrm{St}$ binding ${ }^{(3)}$} & \\
\hline & & & & \multirow{2}{*}{$\mathbf{T}$} & \multirow{2}{*}{$\mathbf{E 2}$} & & \multicolumn{2}{|c|}{ C18 steroids } & \multicolumn{4}{|c|}{ C19 steroids } & \multicolumn{4}{|c|}{ C21 steroids } & \\
\hline & & & & & & & $\mathbf{E 2}$ & E1 & $\mathbf{T}$ & A4 & DHT & 11KT & $\mathbf{P 4}$ & 17,20P & $20 \beta S$ & $\mathbf{F}$ & \\
\hline \multicolumn{18}{|c|}{ CHONDRICHTHYES (elasmobranchs) } \\
\hline \multicolumn{18}{|l|}{ Rajiformes } \\
\hline \multirow{4}{*}{ Raja radiata } & \multirow{3}{*}{ Serum, Dial. $3^{\circ} \mathrm{C}$} & $\mathrm{M}$ & $\mathrm{M}$ & & & & 101 & (a) & 100 & 46 & & & 130 & & & 63 & Freeman and Idler, $1969^{4}$ \\
\hline & & $\mathrm{M}$ & IMM & 17.4 & & & 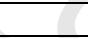 & $\mathrm{N}$ & & & & & & & & & \multirow{2}{*}{ Freeman and Idler, 1971} \\
\hline & & $\mathrm{F}$ & IMM & 12.3 & & & & 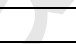 & & & & & & & & & \\
\hline & P.P.F., Dial. $3^{\circ} \mathrm{C}$ & $\mathrm{M}$ & $\mathrm{M}$ & & & $\mathrm{T}$ & 110 & 76 & 100 & 2 & & & 118 & & & 19 & Freeman and Idler, $1969^{4,5}$ \\
\hline \multicolumn{18}{|c|}{ Carcharhiniformes } \\
\hline \multirow{7}{*}{$\begin{array}{l}\text { Scyliorhinus } \\
\text { canicula }\end{array}$} & & $\mathrm{F}$ & IMM & 10.9 & 2.1 & 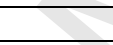 & +1 & & & & & & & & & & \\
\hline & & $\mathrm{F}$ & $\mathrm{M}$ & 13.3 & 2.9 & & & & & & & & & & & & \\
\hline & Serum Dial $4^{\circ} \mathrm{C}$ & $\mathrm{M}$ & $\mathrm{M}$ & 13.3 & 2.8 & & 8 & & & & & & & & & & \\
\hline & Serum, Dial. $4 \mathrm{C}$ & & & & & $\mathrm{T}$ & 275 & & 100 & & & & 413 & & & & Martin, $1975^{6}$ \\
\hline & & & & & & E2 & 100 & & 35 & & & & 50 & & & & \\
\hline & & & & & & $\mathrm{P} 4$ & 133 & & 64 & & & & 100 & & & & \\
\hline & P.P.F., Dial. $4^{\circ} \mathrm{C}$ & & & & $\bar{c}$ & $\mathrm{P} 4$ & 104 & 76 & 51 & 8.5 & 98 & & 100 & & & 15 & \\
\hline Squaliformes & & & & & 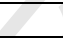 & & & & & & & & & & & & \\
\hline & & $\mathrm{M}$ & $\mathrm{M}$ & & 39 & & & & & & & & & & & & Hoet al $1090^{7}$ \\
\hline Squalus acanthias & Plasma, DCC, $4^{\circ} \mathrm{C}$ & $\mathrm{F}$ & $\mathrm{M}$ & 25 & 36 & E2 & 100 & 45 & 1100 & & 245 & & 100 & & & 20 & Ho et al., $1980^{\prime}$ \\
\hline & Testis, G.F., $4^{\circ} \mathrm{C}$ & $\mathrm{M}$ & $\mathrm{M}$ & 2.2 & 2.5 & E2 & 100 & $<10$ & 80 & & 15 & & 55 & & & & Mak and Callard, $1987^{7}$ \\
\hline OSTEICHTHYES & leosts) & & & & & & & & & & & & & & & & \\
\hline Anguilliformes & & & & E & & & & & & & & & & & & & \\
\hline & & $\mathrm{F}_{\mathrm{O}}$ & & & & $\mathrm{T}$ & 66 & 37 & 100 & 90 & 100 & 47 & 36 & & & 0.6 & \\
\hline Anguilla anguilla & Plasma, Dial. & $\mathrm{F}$ & IMM & 1.9 & 5 & E2 & 100 & 25 & 72 & 26 & 55 & 51 & 18 & & & 0 & Quérat et al., 1983 \\
\hline Anguilla japonica & P.P.F, DCC $4^{\circ} \mathrm{C}$ & mixed & IMM & & & $\mathrm{T}$ & 193 & 0.5 & 100 & 0.6 & & 25 & $<0.1$ & $<0.1$ & & $<0.1$ & Chang et al., 1994 \\
\hline & & & & & & $\mathrm{E} 2$ & 100 & $<0.1$ & 73.9 & 0.9 & & 14.9 & $<0.1$ & $<0.1$ & & $<0.1$ & \\
\hline Cypriniformes & & & A & & & & & & & & & & & & & & \\
\hline & Serum DCC $4^{\circ} \mathrm{C}$ & $\mathrm{M} \& \mathrm{~F}$ & $M$ & 19 & 21 & $\mathrm{~T}$ & 20 & 1 & 100 & & 5 & $<1$ & 6 & & & $<0.1$ & Pasmanik and Callard, 1986 \\
\hline Carassius. auratus & Serum, DCC, $4^{\circ} \mathrm{C}$ & $M d \&$ & $M$ & 1.9 & 2.1 & E2 & 100 & $<0.1$ & 75 & & 20 & 2 & 3 & & & $<0.1$ & \\
\hline & Serum, DCC, $4^{\circ} \mathrm{C}$ & $\mathrm{M} \& \mathrm{~F}$ & $\begin{array}{l}\text { Various } \\
\text { stages }\end{array}$ & 2.1 & 1.9 & E2 & 100 & 20 & 100 & 60 & & & 5 & 0.5 & & & $\begin{array}{l}\text { Van Der Kraak and } \\
\text { Biddiscombe, } 1999^{7}\end{array}$ \\
\hline Conrinus carnio & Plasma, DCC, $4^{\circ} \mathrm{C}$ & & & & & $\mathrm{T}$ & 17 & 7 & 100 & 39 & & 4 & 8 & 3 & & 0.2 & Chang and Lee, 1992 \\
\hline сургіnиs carplo & Plasma, DCC, $4^{\circ} \mathrm{C}$ & M\&F & IMM & & & E2 & 100 & & 104 & & 111 & 51 & & & & 0.9 & Kloas et al., 2000 \\
\hline Tinca tinca & Plasma, DCC, $4^{\circ} \mathrm{C}$ & M\&F & IMM & 3.4 & 4.0 & $\mathrm{~T}$ & 19 & & 100 & 162 & & 7 & & 8 & & $<0.1$ & Scott et al., 2005 \\
\hline Imca tinca & Plasma, DCC, $4{ }^{2} \mathrm{C}$ & $M d F^{2}$ & INIM & 3.4 & 4.0 & $\mathrm{~A} 4$ & 10 & & 45 & 100 & & 4 & & 3 & & $<0.1$ & Scott et al., 2005 \\
\hline Danio rerio & R.P. DCC, $4^{\circ} \mathrm{C}$ & & & 1.8 & 2.2 & $\mathrm{~T}$ & 37 & 10 & 100 & 106 & 39 & 11 & 3 & 2 & & $<0.3$ & Miguel-Queralt et al., 2004 \\
\hline $\begin{array}{l}\text { Catostomus } \\
\text { commersoni }\end{array}$ & Plasma, DCC, $4^{\circ} \mathrm{C}$ & & & 0.9 & 2.7 & E2 & 100 & 15 & 313 & 87 & & & 15 & & & 0.3 & Pruce-Hobbyet al 20038 \\
\hline $\begin{array}{l}\text { Catostomus } \\
\text { catostomus }\end{array}$ & Plasma, DCC, $4^{\circ} \mathrm{C}$ & & & 1.9 & 3.1 & E2 & 100 & 9 & 165 & 82 & & & 11 & & & 0.2 & Pryce-Hodoy et al., 20038 \\
\hline
\end{tabular}




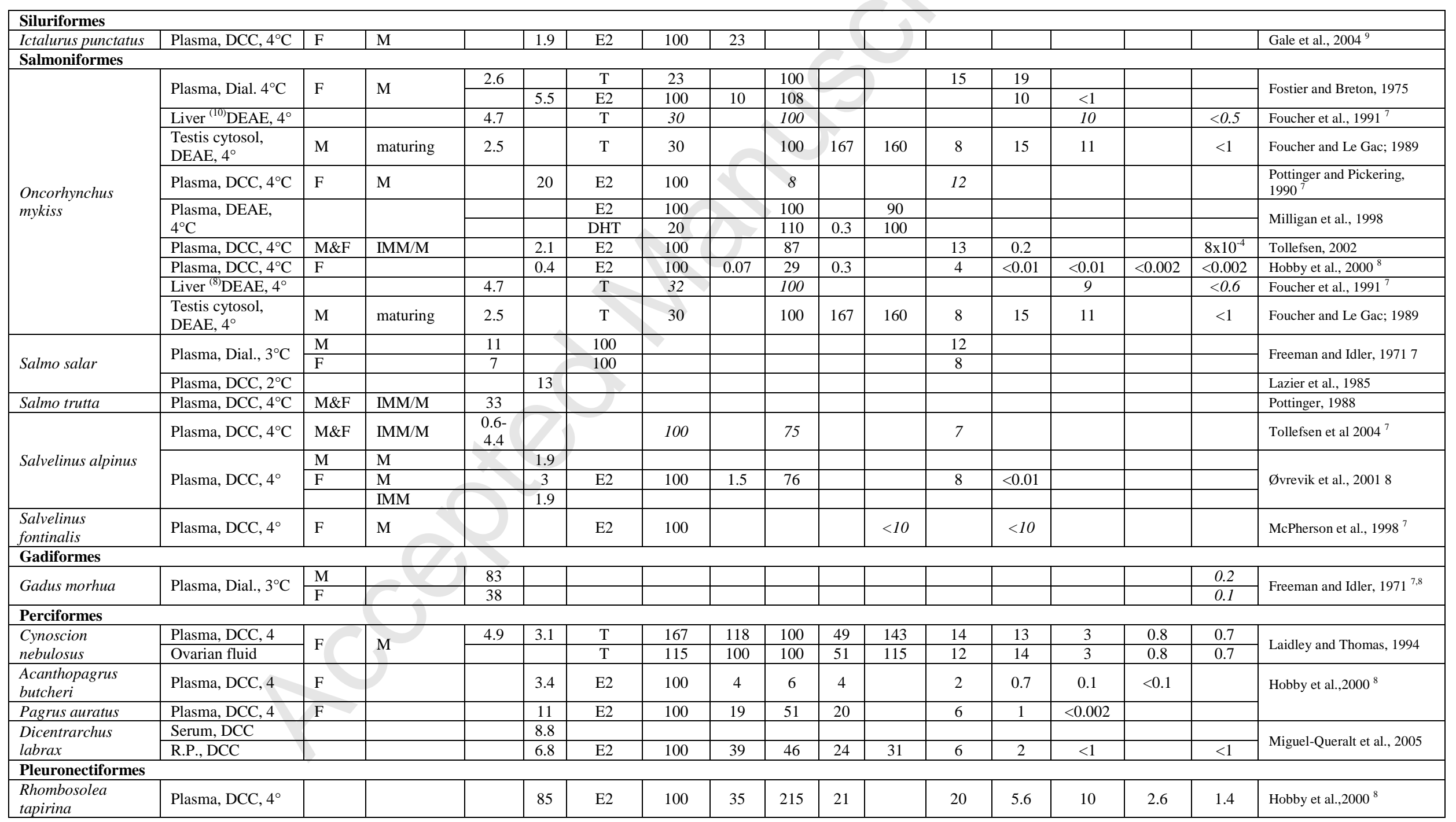


Table 3: Comparison of binding characteristics between fish Shbg and T or E2 nuclear receptors

\begin{tabular}{|c|c|c|c|c|c|c|c|c|}
\hline Species & Tissue & $\begin{array}{c}\text { Binding } \\
\text { type }\end{array}$ & $\begin{array}{c}\text { Tritiated } \\
\text { ligand }\end{array}$ & $\begin{array}{c}\text { Kd } \\
(\mathbf{n M})\end{array}$ & $\begin{array}{c}\begin{array}{c}\text { Time of } \\
\text { equilibrium }\end{array} \\
\end{array}$ & $\begin{array}{c}\text { Half-life of } \\
\text { Dissociation }\end{array}$ & $\begin{array}{c}\text { DNA } \\
\text { binding }\end{array}$ & References \\
\hline \multirow{5}{*}{$\begin{array}{l}\text { Squalus } \\
\text { acanthias }\end{array}$} & \multirow[t]{2}{*}{ Plasma } & \multirow{3}{*}{ Shbg } & \multirow{4}{*}{ E2 } & 35.7 & $<5 \min$ & $100 \mathrm{~min}$ & & $\begin{array}{l}\text { Ho et al., } \\
1980\end{array}$ \\
\hline & & & & & & $<30 \min$ & & Mak and \\
\hline & \multirow{3}{*}{ Testis } & & & 2.5 & $45 \mathrm{~min}$ & $160 \mathrm{~min}$ & - & $\begin{array}{l}\text { Callard, } \\
1987\end{array}$ \\
\hline & & \multirow[b]{2}{*}{ Receptor } & & 1.5 & $30 \mathrm{~min}$ & & + & $\begin{array}{l}\text { (Callard and } \\
\text { Mak, 1985) }\end{array}$ \\
\hline & & & $\mathrm{T}$ & 4.4 & $4 \mathrm{~h}$ & $4 h$ & & $\begin{array}{l}\text { Cuevas and } \\
\text { Callard, } \\
1992 \\
\end{array}$ \\
\hline \multirow{2}{*}{$\begin{array}{l}\text { Cyprinus } \\
\text { carpio }\end{array}$} & Plasma & Shbg & \multirow[b]{2}{*}{ E2 } & & $15 \mathrm{~min}$ & & $\nabla$ & \multirow{2}{*}{$\begin{array}{l}\text { Kloas et al., } \\
2000\end{array}$} \\
\hline & $\begin{array}{c}\text { Liver } \\
\text { (female) }\end{array}$ & Receptor & & 2.1 & $12 \mathrm{~h}$ & $6 h^{(1)}$ & & \\
\hline \multirow{3}{*}{$\begin{array}{l}\text { Oncorhynchus } \\
\text { mykiss }\end{array}$} & Plasma & \multirow[b]{2}{*}{ Shbga } & E2 & 0.4 & $15 \mathrm{~min}$ & $<5 \min$ & & $\begin{array}{l}\text { Hobby et } \\
\text { al., } 2000\end{array}$ \\
\hline & Testis & & $\mathrm{T}$ & 2.5 & $2 \mathrm{~h}$ & $1-2 \min$ & & $\begin{array}{l}\text { Foucher and } \\
\text { Le Gac, } \\
1989\end{array}$ \\
\hline & $\begin{array}{l}\text { Recombinant } \\
\text { protein }\end{array}$ & Shbgb & $\mathrm{T}$ & 0.8 & $30 \mathrm{~min}$ & $3 \mathrm{~min}$ & & $\begin{array}{l}\text { Bobe et al., } \\
2008 \mathrm{~b}\end{array}$ \\
\hline $\begin{array}{l}\text { Oncorhynchus } \\
\text { kisutch }\end{array}$ & Ovary & Receptor & $\mathrm{Mb}^{(2)}$ & 0.32 & $12 \mathrm{~h}$ & & + & $\begin{array}{l}\text { Fitzpatrick } \\
\text { et al., } 1994\end{array}$ \\
\hline $\begin{array}{l}\text { Salvelinus } \\
\text { alpinus }\end{array}$ & Plasma & Shbg & E2 & 3.0 & $30 \min ^{(1)}$ & $3 \mathrm{~h}$ & & $\begin{array}{l}\emptyset \text { vrevik et } \\
\text { al., } 2001 .\end{array}$ \\
\hline \multirow{2}{*}{ Salmo trutta } & Plasma & Shbg & \multirow{2}{*}{ E2 } & 48 & 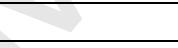 & & + & \multirow{2}{*}{$\begin{array}{l}\text { Pottinger, } \\
1986\end{array}$} \\
\hline & Liver & Receptor & & 2.6 & $\nabla$ & & - & \\
\hline $\begin{array}{l}\text { Cynoscion } \\
\text { nebulosus }\end{array}$ & $\begin{array}{l}\text { Ovary and } \\
\text { plasma }\end{array}$ & Shbg & $\mathrm{T}$ & 4.9 & $5 h^{(1)}$ & $<90 \mathrm{sec}$ & & $\begin{array}{l}\text { Laidley and } \\
\text { Thomas, } \\
1994\end{array}$ \\
\hline
\end{tabular}

(1)The value has been estimated according to graphical data

(2) $\mathrm{Mb}=$ Miborelone, or dimethylnortestosterone, is a potent synthetic androgen 
Table 4 : Binding capacities of fish blood Shbg for testosterone.

\begin{tabular}{|c|c|c|c|}
\hline Species $^{(1)}$ & Bmax (nM) & Bound/Unbound separation ${ }^{(2)}$ & References \\
\hline G. morhua & $1400-3500$ & Dial & Freeman and Idler, 1971 \\
\hline O. mykiss & 2400 & Dial & Fostier and Breton, 1975 \\
\hline S. canicula & $1600-1900$ & Dial & Martin, 1975 \\
\hline S. salar & $900-1900$ & Dial & Freeman and Idler, 1971 \\
\hline A. anguilla & 1700 & Dial & Querat et al., 1983 \\
\hline R. radiata & $700-1400$ & Dial & Freeman and Idler, 1971 \\
\hline O. mykiss & 1300 & Gel Filtration & Fostier and Breton, 1975 \\
\hline O. mykiss & $350-750$ & DEAE Biogel & Foucher and Le Gac, 1989 \\
\hline O. mykiss & 500 & DEAE Biogel & Foucher et al., 1992 \\
\hline C. nebulosus & $300-500$ & DCC; $30 \mathrm{sec} ; 0^{\circ} \mathrm{C} ; 8 \mathrm{mg} / \mathrm{ml}$ & Laidley and Thomas, 1997 \\
\hline S trutta & $130-360$ & $\mathrm{DCC} ; 5 \mathrm{~min} ; 0^{\circ} \mathrm{C} ; 4 \mathrm{mg} / \mathrm{ml}$ & Pottinger, 1988 \\
\hline C. auratus & 270 & $\mathrm{DCC} ; 7 \mathrm{~min} ; 4^{\circ} \mathrm{C} ; 2.5 \mathrm{mg} / \mathrm{ml}$ & Pasmanik and Callard, 1986 \\
\hline T. tinca & 200 & DCC; $1 \mathrm{~min} ; 0^{\circ} \mathrm{C} ; 4 \mathrm{mg} / \mathrm{ml}$ & Scott et al., 2005 \\
\hline S. acanthias & 110 & DCC; $2 \mathrm{~min}, 2.5 \mathrm{mg} / \mathrm{ml}$ & Ho et al, 1980 \\
\hline S. trutta & 24 & DCC $, 10 \mathrm{~min}, 4^{\circ} \mathrm{C}, 7.5 \mathrm{mg} / \mathrm{ml}$ & Pottinger, 1988 \\
\hline
\end{tabular}

(1) Full names are given in table 2. Elasmobranches species are underlined.

(2) Dial = equilibrium dialysis; DCC = dextran coated charcoal. The duration of DCC action before centrifugation, treatment temperature and charcoal concentration are specified, respectively. 
Table 5. Recombinant Shbga and Shbgb binding characteristics

\begin{tabular}{|c|c|c|c|c|c|c|}
\hline & \multicolumn{5}{|c|}{ Species } \\
\hline & & \multicolumn{3}{|c|}{ Shbg/Shbga } & \multicolumn{2}{|c|}{ Shbgb } \\
\hline & & $\begin{array}{l}\text { D. rerio } \\
\text { (1) }\end{array}$ & $\begin{array}{l}\text { D. labrax } \\
\text { (2) }\end{array}$ & $O . k t$ & utch & $\begin{array}{c}\text { O. mykiss } \\
\text { (4) }\end{array}$ \\
\hline \multirow{3}{*}{$\mathrm{Kd}(\mathrm{nM})$} & Androstenedione & 1.8 & & 2.8 & & \\
\hline & Testosterone & & & & & 0.77 \\
\hline & 17ß-Estradiol & 2.2 & 6.8 & & 0.8 & 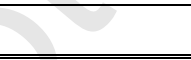 \\
\hline \multirow{2}{*}{\multicolumn{2}{|c|}{ Competitive steroids }} & \multicolumn{5}{|c|}{ Relative binding affinities to: } \\
\hline & & Testosterone & Estradiol & $\begin{array}{l}\text { 5a-dihydro- } \\
\text { testosterone }\end{array}$ & Estradiol & Testosterone \\
\hline \multicolumn{2}{|c|}{ 17ß-Estradiol } & 37.2 & 100 & 31 & 100 & 100 \\
\hline \multicolumn{2}{|l|}{ Estrone } & 9.9 & 38.6 & 21 & $\overline{<0.1}$ & \\
\hline \multicolumn{2}{|l|}{ Estriol } & 1.3 & 1.6 & $<1$ & $<0.1$ & \\
\hline \multicolumn{2}{|c|}{ 2-methoxyestradiol } & $<0.3$ & $<1.0$ & $<1$ & 15 & 26 \\
\hline \multicolumn{2}{|c|}{$17 \alpha$ ethynylestradiol } & & 99.0 & 160 & $<1$ & \\
\hline \multicolumn{2}{|c|}{$\begin{array}{l}\text { Testosterone } \\
\text { Androstenedione }\end{array}$} & $\underline{100}$ & 45.5 & 344 & 30 & $\underline{100}$ \\
\hline \multirow{2}{*}{\multicolumn{2}{|c|}{ 11-ketotestosterone }} & 105 & 24.0 & 365 & $<1$ & \\
\hline & & 10.9 & 5.5 & 57 & 2 & 9 \\
\hline \multicolumn{2}{|c|}{ 5-androstene- $3 \beta, 17 \beta$-diol } & 2.9 & 49.8 & 10 & 58 & \\
\hline \multicolumn{2}{|c|}{ 5 $\alpha$-dihydro-testosterone } & 38.9 & 30.7 & 100 & & 2 \\
\hline \multicolumn{2}{|c|}{ Progesterone } & 3.1 & 2.2 & 9 & $<0.1$ & \\
\hline \multicolumn{2}{|c|}{ 17-hydroxyprogesterone } & & & & & 0.1 \\
\hline \multirow{2}{*}{\multicolumn{2}{|c|}{ 17,20ßdihydroxy 4-pregnen-3-one }} & 2.4 & 1.4 & 12 & $<0.1$ & \\
\hline & & $<0.2$ & $<1.0$ & $<1$ & $<0.1$ & 0.1 \\
\hline
\end{tabular}

See table 2 for relative binding affinity definition

(1) Miguel-Queralt et al., 2004

(2) Miguel-Queralt et al., 2005

(3) Miguel-Queralt et al., 2009

(4) Bobe et al., 2008b. 


\section{Figure legends}

Figure 1. Evolutionary relationships of teleost fishes sex hormone binding proteins (Shbg). This consensus $\mathrm{n} / \mathrm{p} / \mathrm{l}$ tree (fusion of neighbor joining (n), maximum parsimony (p), and maximum likelihood (l) trees) was computed using the FIGENIX platform (Gouret et al., $2005)$ with the $D$. rerio growth arrest-specific 6 (Gas6) protein (AH53117) as an outgroup and the following Shbg proteins dataset: human and mouse Shbg (CAA34398 and

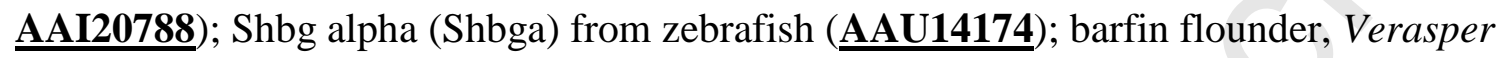

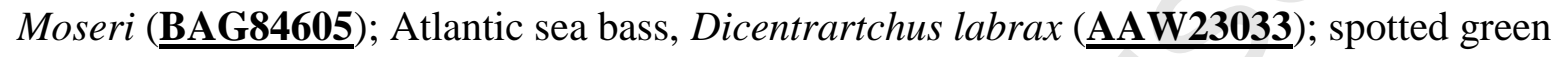

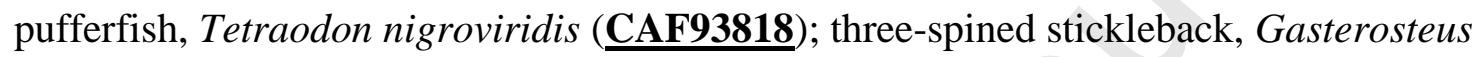
aculeatus (ENSORLP00000008096); Japanese medaka, Oryzias latipes (ENSORLP00000008096); Japanese pufferfish, Takifugu rubipres (ENSTRUP00000031810);

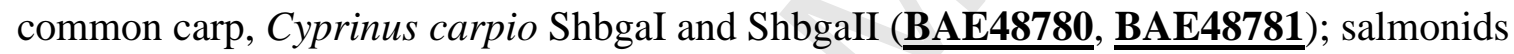
Shbg alpha and Shbg beta (Shbgb) from rainbow trout, Oncorhynchus mykiss (․AE48779,

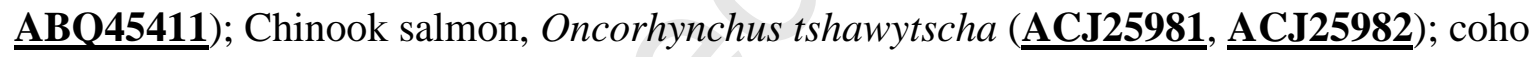
salmon, Oncorhynchus kisutch ( $\underline{\mathbf{A C J 2 5 9 7 9}}, \underline{\mathbf{A C J 2 5 9 8 0}})$. The Atlantic salmon, Salmo salar Shbg partial proteins were deduced from Expressed Sequence Tags matching Shbga (DV106329, $\underline{\text { CK888851 }}$ and $\underline{\text { CK888675) }}$ ) and Shbgb (DY735728, DY694623, DY719210, $\underline{\text { DW561629 }}, \underline{\text { DY699232 }}, \underline{\text { CK884863 }}, \underline{\text { CA056042 }}, \underline{\text { DY699233 }}$, and DY719211). Significant bootstrap values are given in percentage at the main nodes of the consensus tree for each of the n_p_l method used (*: non significant).

Figure 2. Comparison of the structure of different teleost fishes shbga genes. Exons are boxed and lines indicate the introns. Out of scale introns are indicated by broken lines and their lengths are given in bp. Exon numbers are given above exon boxes. All intron-exon boundaries were predicted according to the Ensembl gene prediction for three-spined 
stickleback, Gasterosteus aculeatus (ENSORLP00000008096); Japanese medaka, Oryzias latipes (ENSORLP00000008096) and Japanese pufferfish, Takifugu rubipres (ENSTRUP00000031810).

Figure 3. Alignment of Shbga sequences from zebrafish ( $\underline{\mathbf{A A U 1 4 1 7 4}})$, rainbow trout ( $\underline{\text { BAE48779)}}$, sea bass ( $\underline{\text { AAW23033 }}$ ) with human SHBG $(\underline{\text { CAA34398 }})$ and rainbow trout Shbgb (ABQ45411). Amino-acids sequences conserved in at least 4 sequences are shaded. Amino acid residues specific of the rainbow trout Shbgb are shown below the alignment respectively with a hyphen (-). The conserved cysteine residues are identified below the alignment with a bold type $\mathrm{C}$ letter and the two intra-molecular disulfide bridges (IMDB1 and IMDB2) linking these cysteines are represented. Consensus sites for $\mathrm{N}$-glycosylation are indicated in bold italics. Amino acids corresponding to the signal peptides are underlined and have been obtained from the following published sequences (Miguel-Queralt et al., 2004;Miguel-Queralt et al., 2005). 


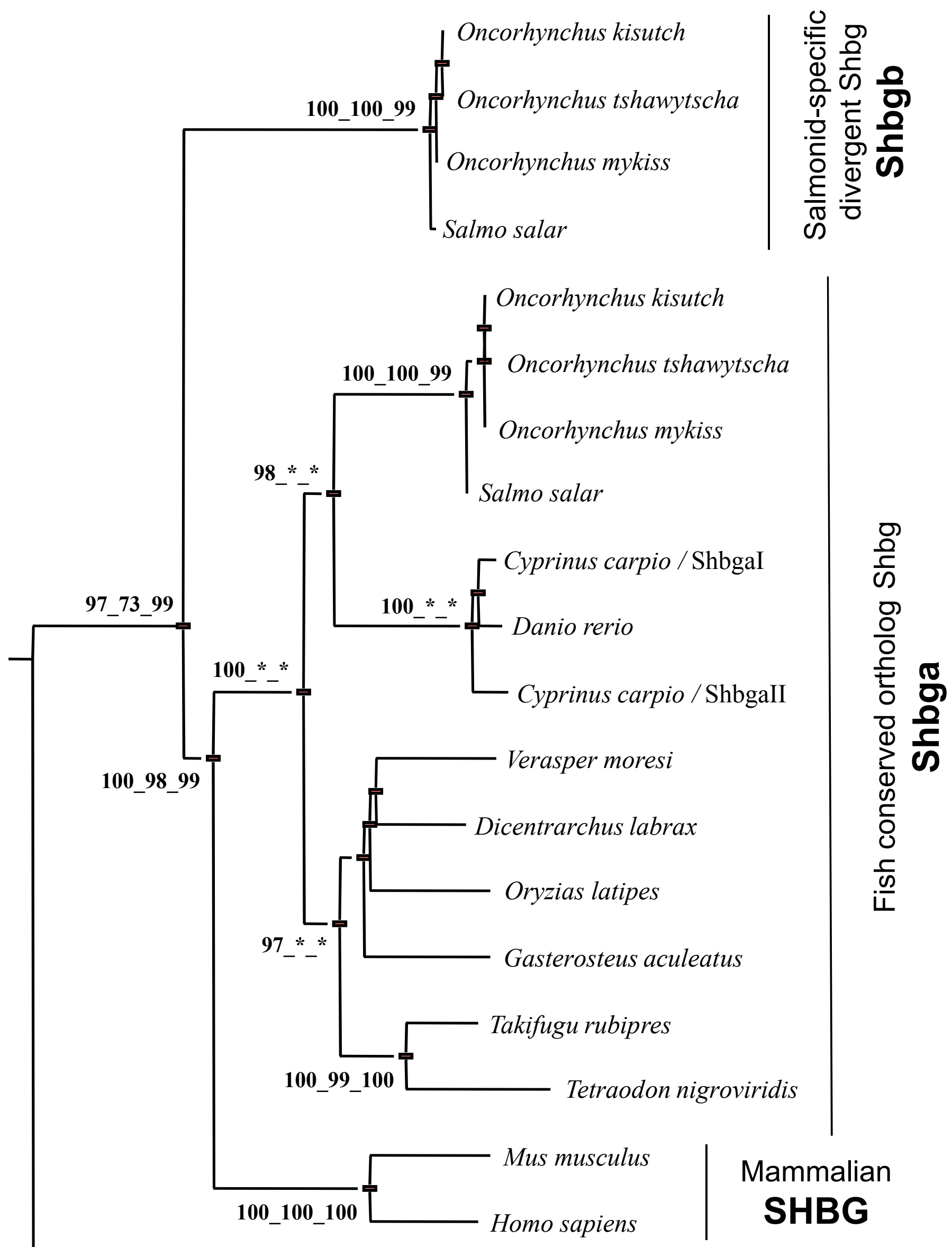

Gas6 Danio rerio 
Shbga D. rerio

Shbga O. mykiss

Shbga D. Iabrax

SHBG H. sapiens

Shbgb O. mykiss

Shbga D. rerio

Shbga O. mykiss

Shbga D. Iabrax

SHBG H. sapiens

Shbgb O. mykiss

Shbga D. rerio

Shbga O. mykiss

Shbga D. Iabrax

SHBG H. sapiens

shbgb O. mykiss

Shbga D. rerio

Shbga O. mykiss

Shbga D. Iabrax

SHBG H. sapiens

Shbgb O. mykiss

Shbga D. rerio

Shbga O. mykiss

Shbga D. Iabrax

SHBG H. sapiens

Shbgb 0 . mykiss

M-KYLKEVI-ILLLCPC LILLCRRAAGDO-------ISGRGTINLAHROO-KWTPAMOTCANLSDIRS IRSFFEFRTLDPEGAVFYGDTK 80 M-GSLKTLSGGLLLGLCLTLLGWGAEGQWNGHPKKEISGSGPINLGQQQRGTWWPLMQTRENLTEVKS IKSMFQFRTFDPEGVVFYGDTR 89 MVTVWKVMAGLLLTLSLTLIGWGAEGQQNRREKKEVSGSTSVYLGQERD-IWRPLI HTTVNLSEIRS IKSSFQFR TFDPEGAIFYGDTK 89 MESRGPLATSRLLLLLLLLLLRHTRQGWALRPVLPTQSAHDPPAVHLSNGPGQEPIAVMTFDLTKITKTSSSFEVR TWDPEGVIFY GDTN 90 M-FALKRFVVALLTLGIWVHPTLGRTLEPS PECYYFVESRSSHLLYTGNS-SVGNVPILEYKVTELTSFDSEFELR TLDPEGVIFFGDIG 88 $-----$$$
-
$$ 


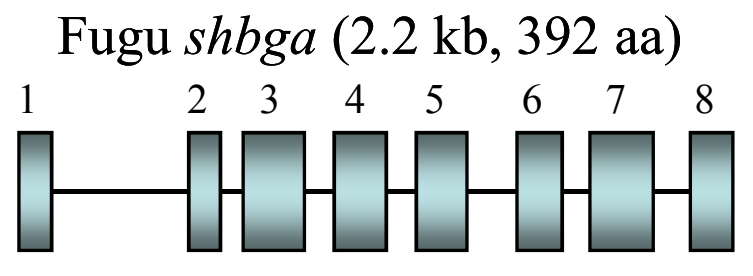

Stickleback shbga (4 kb, 394 aa)

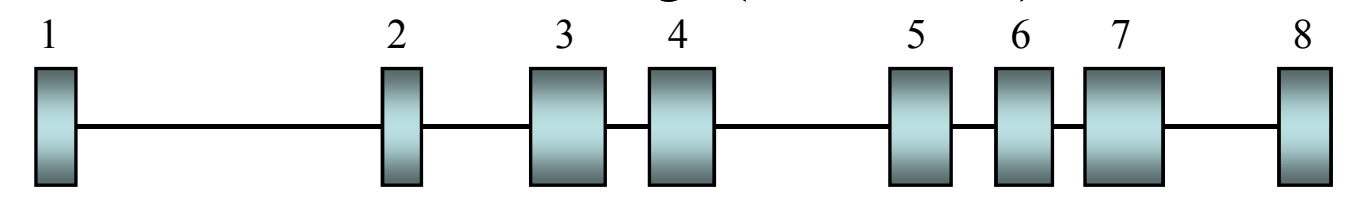

Medaka shbga (6.8 kb, $385 \mathrm{aa})$
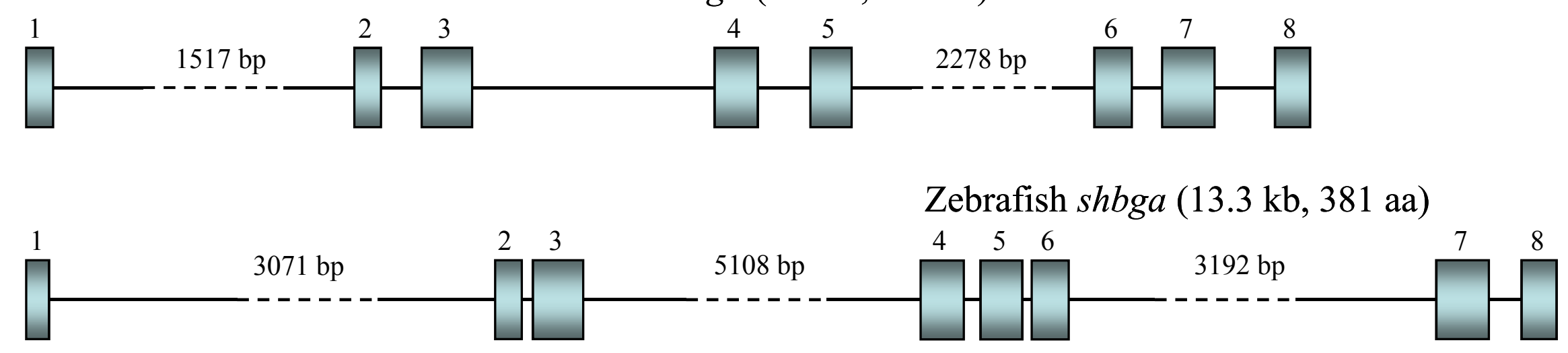